\title{
Intramammary 25-hydroxyvitamin $\mathrm{D}_{3}$ treatment modulates innate immune responses to endotoxin-induced mastitis
}

\author{
Kathryn E. Merriman, ${ }^{*}$ Jessi L. Powell, $\dagger$ Jose E. P. Santos, $\nmid$ and Corwin D. Nelson ${ }^{1}$ \\ ${ }^{*}$ Animal Molecular and Cellular Biology Graduate Program and \\ †Department of Animal Sciences, University of Florida, Gainesville 32611
}

\begin{abstract}
Vitamin D signaling in response to pathogen-associated molecules contributes to activation of innate immune responses of bovine monocytes. We hypothesized that lipopolysaccharide (LPS) of bacteria associated with mastitis in dairy cows activates the vitamin D pathway in innate immune cells of the udder and that increasing availability of 25-hydroxyvitamin $\mathrm{D}_{3}[25(\mathrm{OH})$ $\mathrm{D}_{3}$ ] would augment expression of vitamin D-associated genes. The objective of this experiment was to determine the effects of intramammary LPS and $25(\mathrm{OH}) \mathrm{D}_{3}$ treatments on activation of the vitamin $\mathrm{D}$ pathway and innate immune responses of mammary immune cells. Individual mammary quarters of 5 lactating cows were treated with placebo control, $100 \mu \mathrm{g}$ of $25(\mathrm{OH}) \mathrm{D}_{3}, 5 \mu \mathrm{g}$ of LPS, or a combination of $100 \mu \mathrm{g}$ of $25(\mathrm{OH}) \mathrm{D}_{3}$ and $5 \mu \mathrm{g}$ of LPS. Somatic cells from milk were evaluated for percentage of neutrophil and macrophage populations and expression of genes associated with vitamin D metabolism and innate immunity. Data from samples collected from 4 to $12 \mathrm{~h}$ after challenge were analyzed for main effects of LPS and $25(\mathrm{OH}) \mathrm{D}_{3}$ treatments, treatment interactions, and simple effects of $25(\mathrm{OH}) \mathrm{D}_{3}$ treatment. Data from samples collected at the time of challenge were used as covariates. The percentages of neutrophils in milk at $8 \mathrm{~h}$ postchallenge were $58 \pm 10$, $82 \pm 11,89 \pm 10$, and $63 \pm 10 \%$ of total cells in milk from control, 25(OH) $\mathrm{D}_{3}$, LPS, and LPS plus $25(\mathrm{OH})$ $\mathrm{D}_{3}$ glands, respectively, such that the interaction of LPS and $25(\mathrm{OH}) \mathrm{D}_{3}$ was significant. Expression of the vitamin $\mathrm{D} 1 \alpha$-hydroxylase $\left(C Y \mathrm{P}^{2} 7 B 1\right)$ and vitamin $\mathrm{D}$ receptor genes was upregulated by LPS treatment in total cells, macrophages, and neutrophils in milk. In addition, expression of the vitamin D 24-hydroxylase (CYP24A1) gene in milk somatic cells was upregulated
\end{abstract}

Received November 16, 2017.

Accepted March 13, 2018.

${ }^{1}$ Corresponding author: cdnelson@ufl.edu by $25(\mathrm{OH}) \mathrm{D}_{3}$ and LPS treatments. The inducible nitric oxide synthase $(i N O S)$, chemokine (C-C-motif) ligand 5 (CCL5), $\beta$-defensin 3 (DEFB3), DEFB 7, and DEFB10 genes were upregulated by LPS treatment in total cells and neutrophils from milk. Expression of $i N O S$ in milk somatic cells tended to be affected by the interaction between LPS and $25(\mathrm{OH}) \mathrm{D}_{3}$, such that $25(\mathrm{OH}) \mathrm{D}_{3}$ tended to increase $i N O S$ in the absence of LPS but not in the presence of LPS. Furthermore, expression of CCL5 in macrophages was downregulated by $25(\mathrm{OH})$ $\mathrm{D}_{3}$. In conclusion, intramammary endotoxin challenge activates the vitamin $\mathrm{D}$ pathway in mammary macrophages and neutrophils, and intramammary $25(\mathrm{OH})$ $\mathrm{D}_{3}$ treatment alters the percentage of neutrophils and expression of immune genes in milk somatic cells.

Key words: vitamin D, innate immunity, mastitis, dairy cow

\section{INTRODUCTION}

Mastitis in dairy cattle is a major concern in regards to animal welfare, milk quality, and profitability for dairy producers, and it eventually affects consumers (Ruegg, 2012). Mastitis is almost always caused by infection of the mammary gland, and environmental bacterial pathogens such as Escherichia coli and Streptococcus uberis are the most common agents in farms that have adopted control measures for mastitis. The innate response of the mammary gland to a bacterial pathogen triggers an influx of immune cells, primarily neutrophils, and production of inflammatory cytokines and bactericidal molecules (Rainard and Riollet, 2006). Although the innate immune response to bacterial infections of the mammary gland has been well-characterized, a better understanding of the mechanisms influencing innate defenses of the mammary gland is needed to improve treatment and prevention efforts for mastitis.

Several reports using models of cattle, human, and rodent innate immune responses have documented a role for vitamin $\mathrm{D}$ in the innate immune response to pathogens. Specifically in cattle, pathogen-associated 
molecules such as LPS and peptidoglycan stimulated expression of the 25-hydroxyvitamin D $1 \alpha$-hydroxylase (CYP27B1) in cultures of peripheral blood monocytes (Nelson et al., 2010b, 2011). The CYP27B1 enzyme catalyzes conversion of 25-hydroxyvitamin $\mathrm{D}_{3}[\mathbf{2 5}(\mathbf{O H})$ $\left.\mathbf{D}_{3}\right]$ to the active vitamin $\mathrm{D}$ hormone, 1,25-dihydroxyvitamin $\mathrm{D}_{3}\left[\mathbf{1}, \mathbf{2 5}(\mathbf{O H})_{2} \mathbf{D}_{3}\right]$. The $1,25(\mathrm{OH})_{2} \mathrm{D}_{3}$ primarily acts to regulate gene expression upon its association with intracellular vitamin D receptors (VDR). Synthesis of $1,25(\mathrm{OH})_{2} \mathrm{D}_{3}$ from $25(\mathrm{OH}) \mathrm{D}_{3}$ in LPS-stimulated cultures of bovine monocytes upregulated expression of $\beta$-defensin $(D E F B) 3, D E F B 4, D E F B 6, D E F B 7$, $D E F B 10$, inducible nitric oxide synthase (iNOS), and chemokine (C-C motif) ligand 5 (CCL5) genes (Nelson et al., 2010b; Merriman et al., 2015). Altogether, these data indicate a potential for targeted enhancement of defense against bacterial infections via the vitamin $\mathrm{D}$ pathway.

In regards to mastitis, a role for vitamin $\mathrm{D}$ signaling in defense of the mammary gland has been indicated in dairy cows. Mammary tissue and somatic cells isolated from milk of quarters experimentally infected with $S$. uberis had increased expression of CYP27B1, VDR, and the gene for the 25-hydroxtvitamin D 24-hydroxylase (CYP24A1) compared with healthy control quarters (Nelson et al., 2010a). Furthermore, Lippolis et al. (2011) tested the effects of intramammary $25(\mathrm{OH}) \mathrm{D}_{3}$ treatment on the outcomes of experimental $S$. uberis mastitis on the basis that vitamin D signaling is activated during mastitis and observed reduced signs of mastitis in cows treated with intramammary $25(\mathrm{OH})$ $\mathrm{D}_{3}$. The authors proposed that intramammary $25(\mathrm{OH})$ $\mathrm{D}_{3}$ treatments enhanced defense against $S$. uberis infection by increasing immune cell $1,25(\mathrm{OH})_{2} \mathrm{D}_{3}$ synthesis in the infected quarters. Indeed, the $1,25(\mathrm{OH})_{2} \mathrm{D}_{3}$ metabolite does influence expression of vitamin $\mathrm{D}$-associated genes in the mammary gland (Merriman et al., 2017). However, the influence of $25(\mathrm{OH}) \mathrm{D}_{3}$ on mammary immune responses to bacterial pathogens has not been determined.

Intramammary LPS challenge induces acute mastitis in dairy cows and has been used as a model to characterize the innate immune response to bacterial pathogens (Bannerman et al., 2003; Schmitz et al., 2004). We hypothesized that intramammary LPS would stimulate CYP27B1 activity in the mammary gland and that simultaneous intramammary $25(\mathrm{OH}) \mathrm{D}_{3}$ would enhance immune responses associated with vitamin $\mathrm{D}$ signaling in cattle. Therefore, the objective of this experiment was to determine the effects of intramammary LPS and $25(\mathrm{OH}) \mathrm{D}_{3}$ treatments on activation of the vitamin $\mathrm{D}$ pathway and innate immune responses of the mammary gland.

\section{MATERIALS AND METHODS}

\section{Animals}

Five healthy lactating Holstein cows at the University of Florida's Dairy Unit (Hague, FL) were used for this experiment. Cows were between 300 and 680 DIM, not pregnant, free of mastitis (milk SCC $\leq 200,000$ cells/ $\mathrm{mL}$ ), and otherwise healthy by appearance. Cows were milked twice per day and fed a diet formulated to meet the needs of lactating dairy cows (NRC, 2001). The diet was fed as a TMR and was estimated to provide approximately 40,000 IU of vitamin $\mathrm{D}_{3} / \mathrm{d}$, which is normal for dairy cows in the United States and typically achieves between 50 and $80 \mathrm{ng} / \mathrm{mL}$ of $25(\mathrm{OH}) \mathrm{D}_{3}$ in serum (Nelson et al., 2016a). The University of Florida's Institute of Food and Agricultural Sciences Animal Research Committee approved all procedures for the care and treatment of the animals.

\section{Intramammary LPS and 25(OH)D $D_{3}$ Treatment}

The $25(\mathrm{OH}) \mathrm{D}_{3}$ was purchased in crystalline form from Cayman Chemical (Ann Arbor, MI) and dissolved to a concentration of $10 \mathrm{mg} / \mathrm{mL}$ in ethanol. The concentration and purity of $25(\mathrm{OH}) \mathrm{D}_{3}$ was confirmed by UV absorption spectroscopy at 228- and 264-nm wavelengths using a molar extinction coefficient of 18,200 $M^{-1} \mathrm{~cm}^{-1}$. For intramammary $25(\mathrm{OH}) \mathrm{D}_{3}$ treatments, $100 \mu \mathrm{g}$ of $25(\mathrm{OH}) \mathrm{D}_{3}$ was diluted in $10 \mathrm{~mL}$ of sterile PBS (Dulbecco's PBS without calcium or magnesium; Hyclone, Logan, UT) supplemented with $10 \%$ fetal bovine serum as a carrier for $25(\mathrm{OH}) \mathrm{D}_{3}$ (characterized serum; Hyclone). The LPS from E. coli 026:B6 was purchased in crystalline form from Sigma-Aldrich (St. Louis, MO) and dissolved to a concentration of $5 \mathrm{mg} / \mathrm{mL}$ in sterile $\mathrm{H}_{2} \mathrm{O}$. Ten-milliliter solutions of PBS containing $5 \mu \mathrm{g}$ of LPS (LIPO), $100 \mu \mathrm{g}$ of $25(\mathrm{OH}) \mathrm{D}_{3}(\mathbf{2 5 D}), 5 \mu \mathrm{g}$ of LPS and $100 \mu \mathrm{g}$ of $25(\mathrm{OH}) \mathrm{D}_{3}(\mathbf{L I P O}+\mathbf{2 5 D})$, or no LPS or $25(\mathrm{OH}) \mathrm{D}_{3}$ (control) were prepared for intramammary treatment. The amount of $25(\mathrm{OH}) \mathrm{D}_{3}$ used was selected on the basis of previous research that showed it did not alter concentrations of $25(\mathrm{OH}) \mathrm{D}_{3}$ in serum and had inhibitory effects on S. uberis mastitis (Lippolis et al., 2011).

\section{Experimental Design}

The experiment was a randomized complete block design with a factorial arrangement of treatments. Individual mammary quarters of each cow were considered the experimental units, and cow was the blocking factor. The model used gland-specific responses as previ- 
ously shown with LPS models (Schmitz et al., 2004). The control, 25D, LIPO, and LIPO+25D solutions were randomly assigned to each quarter of the 5 cows and aseptically administered via a teat cannula. The quarters administered LPS $+25 \mathrm{D}$ treatments received repeated treatments with $100 \mu \mathrm{g}$ of $25(\mathrm{OH}) \mathrm{D}_{3}$ solution at 12,24 , and $36 \mathrm{~h}$ following initial challenge to test the effects of 25-hydroxyvitamin $\mathrm{D}_{3}$ on the duration of the mammary response to LPS. Accordingly, data collected after $12 \mathrm{~h}$ were analyzed separately from data collected from 0 to $12 \mathrm{~h}$.

\section{Body Temperature and Milk SCC Determination}

Rectal temperatures were measured at $0,4,8,12,24$, $36,48,72$, and $96 \mathrm{~h}$ to assess the febrile response. The SCC in milk were determined at $0,12,24,36,48,72$, and $96 \mathrm{~h}$ relative to challenge. Prior to full milk withdrawal, foremilk samples were collected into 48-mL collection tubes that contained bronopol as a preservative. Samples were then shipped overnight to Belleview Lab Southeast Milk Inc. (Belleview, FL) for determination of SCC by flow cytometry. Somatic cell counts were log-transformed for statistical analysis and reported as $\log _{10}$ of SCC.

\section{Collection of Milk Somatic Cells and Blood Leukocytes for Gene Expression}

Fifty milliliters of milk was collected from each gland at $0,4,8,12,24,36,48$, and $72 \mathrm{~h}$ relative to the challenge for analysis of gene expression in milk somatic cells. The milk samples collected at 12-h intervals were collected before normal milking. An additional $50 \mathrm{~mL}$ of milk was collected at 0 and $8 \mathrm{~h}$ for analysis and separation of macrophages and neutrophils. Milk samples were collected into $50-\mathrm{mL}$ conical tubes before full milk withdrawal and transported to the laboratory on ice. Samples were centrifuged at $1,500 \times g$ for $20 \mathrm{~min}$ to pellet the cells. The cell pellet was then resuspended in $10 \mathrm{~mL}$ of PBS and centrifuged again to wash the somatic cells. The cells were placed in Trizol Reagent (Life Technologies, Carlsbad, CA) and stored at $-80^{\circ} \mathrm{C}$ for later RNA isolation. Blood was sampled from coccygeal vessels into 8-mL lithium heparin evacuated tubes (Vacutainer, Becton Dickinson, Franklin Lakes, $\mathrm{NJ})$ at 0 and $8 \mathrm{~h}$ relative to the treatment for isolation of monocytes and neutrophils.

For the isolation of macrophages and neutrophils from milk and blood, total somatic cells were isolated from 50-mL milk samples as above, and total blood leukocytes were collected from $1 \mathrm{~mL}$ of heparinized blood by hypotonic lysis of erythrocytes. Cells from milk and blood were then incubated for $30 \mathrm{~min}$ on ice with allophycocyanin-conjugated anti-CD14 (Tük4 clone, Life Technologies) and fluorescein isothiocyanate-conjugated mouse anti-bovine CD11b (CC126 clone; AbD Serotec, Raleigh, NC) in $100 \mu \mathrm{L}$ of PBS containing $0.5 \%$ bovine serum albumin (Fisher Scientific, Fair Lawn, NJ) and 2 mM EDTA (Fisher Scientific). Cells were then sorted on the basis of size, granularity, and intensity of fluorescein isothiocyanate and allophycocyanin fluorescence as previously described (Merriman et al., 2017) using a Sony SH800 cell sorter equipped with 405-, 488-, and 633-nm lasers (Sony Biotechnology Inc., San Jose, CA). The

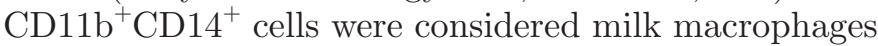
or blood monocytes, and $\mathrm{CD}_{11} \mathrm{~b}^{+} \mathrm{CD} 14^{-}$cells were

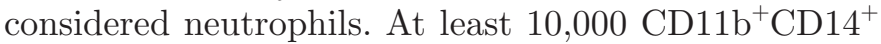

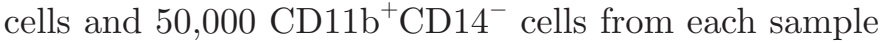
were collected with $>95 \%$ purity. The sorted cells were then pelleted and lysed with RNA lysis buffer from Quick-RNA MiniPrep (Zymo Research, Irvine, CA) for later RNA isolation.

\section{Measurement of Gene Expression}

Total milk somatic cell RNA was processed using Trizol Reagent (Life Technologies) according to the manufacturer's instructions and resuspended with 50 $\mu \mathrm{L}$ of RNase-free water. The RNA concentration and quality were assessed by measuring absorbance at 260 and $280 \mathrm{~nm}$ using a NanoDrop ND-2000 spectrophotometer (Thermo Scientific, Waltham, MA). Samples were diluted with RNase-free water to obtain an RNA concentration of $100 \mathrm{ng} / \mu \mathrm{L}$. The RNA was reverse transcribed to cDNA using High Capacity cDNA Reverse Transcription Kit with RNAase inhibitor (Life Technologies) in a $20-\mu \mathrm{L}$ reaction that contained 10 $\mu \mathrm{L}$ of RNA sample. Reactions were incubated at $23^{\circ} \mathrm{C}$ for $10 \mathrm{~min}$, followed by $2 \mathrm{~h}$ at $37^{\circ} \mathrm{C}$ and $5 \mathrm{~min}$ at $85^{\circ} \mathrm{C}$. The cDNA samples were diluted 1:10 with DNase-free water and stored at $-20^{\circ} \mathrm{C}$. Quantitative PCR was performed using a 7300 Real-Time PCR System (Applied Biosystems, Carlsbad, CA) with gene-specific primers listed in Table 1. Amplifications were performed in a $20-\mu \mathrm{L}$ reaction that contained $10 \mu \mathrm{L}$ of SYBR Select qPCR master mix (Life Technologies), $0.5 \mu \mathrm{L}$ each of $10 \mu M$ forward and reverse primers, and $9 \mu \mathrm{L}$ of the 1:10 diluted cDNA sample. Reactions were incubated at $95^{\circ} \mathrm{C}$ for $10 \mathrm{~min}$, followed by 40 cycles of $95^{\circ} \mathrm{C}$ for 15 $\mathrm{s}$ and $60^{\circ} \mathrm{C}$ for $1 \mathrm{~min}$.

For determination of relative transcript abundance, the threshold cycle $\left(\mathbf{C}_{\mathbf{t}}\right)$ for each gene in each cDNA sample was normalized to the reference gene ribosomal 
Table 1. Quantitative PCR primer sequences

\begin{tabular}{|c|c|c|c|}
\hline Gene $^{1}$ & Accession no. ${ }^{2}$ & Strand $^{3}$ & Sequence $\left(5^{\prime}-3^{\prime}\right)$ \\
\hline \multirow[t]{2}{*}{$\overline{D E F B 3}$} & NM_001282581.1 & $\mathrm{F}$ & CTCCTCGCACTCCTCTTCCT \\
\hline & & $\mathrm{R}$ & GCATCTTCGCCTTCTTCTACCACGA \\
\hline \multirow{2}{*}{ DEFB 4} & NM_174775.1 & $\mathrm{F}$ & TCCTCGCAGTCCTCTTCCT \\
\hline & & $\mathrm{R}$ & GGCACAAGAACGGAATACAGA \\
\hline \multirow[t]{2}{*}{ DEFB5 } & NM_001130761.1 & $\mathrm{F}$ & CTCCTCGTGCTCCTCTTCC \\
\hline & & $\mathrm{R}$ & ACGGCAGCTTTGAGGATTT \\
\hline \multirow[t]{2}{*}{$D E F B 7$} & NM_001102362.2 & $\mathrm{F}$ & TCTTCCTGGTCCTGTCTGCT \\
\hline & & $\mathrm{R}$ & GGTGCCAATCTGTCTCCTGT \\
\hline \multirow[t]{2}{*}{ DEFB10 } & NM_001115084.1 & $\mathrm{F}$ & CTCCTCCTGCTCCTCTTGGT \\
\hline & & $\mathrm{R}$ & TGCCAATCTGTCTCATGCGT \\
\hline \multirow[t]{2}{*}{$C C L 5$} & NM_175827 & $\mathrm{F}$ & CACCCACGTCCAGGAGTATT \\
\hline & & $\mathrm{R}$ & CTCGCACCCACTTCTTCTCT \\
\hline \multirow[t]{2}{*}{$C Y{ }^{2} 27 B 1$} & NM_001192284.1 & $\mathrm{F}$ & TGGGACCAGATGTTTGCATTCGC \\
\hline & & $\mathrm{R}$ & TTCTCAGACTGGTTCCTCATGGCT \\
\hline \multirow[t]{2}{*}{ CYP24A1 } & NM_001191417.1 & $\mathrm{F}$ & GAAGACTGGCAGAGGGTCAG \\
\hline & & $\mathrm{R}$ & CAGCCAAGACCTCGTTGATT \\
\hline \multirow[t]{2}{*}{$I L 1 B$} & NM_174093 & $\mathrm{F}$ & GCCTTGGGTATCAAGGACAA \\
\hline & & $\mathrm{R}$ & TTTGGGGTCTACTTCCTCCA \\
\hline \multirow[t]{2}{*}{$I L 8$} & NM_173925 & $\mathrm{F}$ & TGCTCTCTGCAGCTCTGTGT \\
\hline & & $\mathrm{R}$ & GGTGGAAAGGTGTGGAATGT \\
\hline \multirow[t]{2}{*}{$i N O S$} & NM_001076799.1 & $\mathrm{F}$ & GATCCAGTGGTCGAACCTGC \\
\hline & & $\mathrm{R}$ & CAGTGATGGCCGACCTGATG \\
\hline \multirow[t]{2}{*}{$R P S 9$} & NM_001101152.2 & $\mathrm{F}$ & GTGAGGTCTGGAGGGTCAAA \\
\hline & & $\mathrm{R}$ & GGGCATTACCTTCGAACAGA \\
\hline \multirow[t]{2}{*}{$V D R$} & NM_001167932.1 & $\mathrm{F}$ & GAGGGGAACCGTCCTTTGAG \\
\hline & & $\mathrm{R}$ & GAGAAGCTGGTTGGCTCCAT \\
\hline
\end{tabular}

${ }^{1}$ Primer sequences for transcripts of bovine $\beta$-defensins (DEFB3, DEFB4, DEFB5, DEFB7, DEFB10), chemokine (C-C motif) ligand 5 (CCL5), 25-hydroxyvitamin D 1 $\alpha$-hydroxylase (CYP27B1), 25-hydroxyvitamin D 24-hydroxylase (CYP24A1), IL-1 $\beta$ (IL1B), IL-8 (IL8), inducible nitric oxide synthase (iNOS), ribosomal protein S9 (RPS9), and vitamin D receptor ( $V D R)$. Sequences have been published previously.

${ }^{2}$ Accesion numbers from National Center for Biotechnology Information database (http://www.ncbi.nlm.nih. gov).

${ }^{3} \mathrm{~F}=$ forward; $\mathrm{R}=$ reverse.

protein $\mathrm{S} 9$ (RPS9) using the formula $\mathrm{C}_{\mathrm{t}}$ (gene of interest) $-\mathrm{C}_{\mathrm{t}}$ (RPS9) $=$ delta $\mathrm{C}_{\mathrm{t}}$ (Merriman et al., 2017). The delta $C_{t}$ values for each gene were used for statistical analysis described below. The mean delta $\mathrm{C}_{t}( \pm \mathrm{SE})$ for each treatment was transformed using the formula $1,000 \times 2^{\text {-delta Ct }}$ to report the relative number of transcripts per 1,000 RPS9 transcripts.

\section{Measurement of 25(OH)D Concentrations}

Combined concentrations of 25-hydroxyvitamin D2 and 25-hydroxyvitamin D3 $[\mathbf{2 5}(\mathbf{O H}) \mathbf{D}]$ in serum and milk samples were measured using a commercially available ELISA (Human $\mathrm{VD}_{3}$ ELISA, Eagle Biosciences, Nashua, NH) using a 25(OH)D standard curve (5 ng/ $\mathrm{mL}$ to $125 \mathrm{ng} / \mathrm{mL}$ ) prepared in bovine serum as previously described (Nelson et al., 2016b). Measurement of absorbance at $450 \mathrm{~nm}$ was made using a BioTek Synergy plate reader (BioTek Instruments Inc., Winooski, $\mathrm{VT}$ ). Inter- and intra-assay coefficients of variation for the ELISA were 5.6 and $4.4 \%$, respectively.

\section{Statistical Analysis}

All data were analyzed using the delta $C_{t}$ values for each gene in SAS version 9.4 (SAS Institute Inc., Cary, NC). The experiment was analyzed as a repeated-measures analysis with the MIXED procedure of SAS. The model accounted for fixed effects of treatment, time, and interaction between treatment and time and the random effects of gland nested within cow and treatment. The Kenward-Roger method was used to calculate the denominator degrees of freedom to approximate the F-tests in the statistical models. Measurements collected at $0 \mathrm{~h}$ for each variable were used as covariates in the analysis. Data from 4 to $12 \mathrm{~h}$ were used to determine main effects of LPS or $25(\mathrm{OH})$ $\mathrm{D}_{3}$ treatments and the interactions between LPS and $25(\mathrm{OH}) \mathrm{D}_{3}$. Data collected after $12 \mathrm{~h}$ were analyzed only for simple effects of 25D or LPS treatments, as glands treated with $\mathrm{LIPO}+25 \mathrm{D}$ received repeated injections of $25(\mathrm{OH}) \mathrm{D}_{3}$ at 12,24 , and $36 \mathrm{~h}$. Tests for multiple comparisons were made with the Tukey-Kramer adjustment. Statistical significance was declared at $P \leq 0.05$, 
and a tendency for significance was declared at $0.05<$ $P \leq 0.10$.

\section{RESULTS}

\section{Clinical Responses to Intramammary LPS and $25(\mathrm{OH}) \mathrm{D}_{3}$ Treatments}

Concentrations of $25(\mathrm{OH}) \mathrm{D}$ in serum were $43 \pm$ $7 \mathrm{ng} / \mathrm{mL}$ (range: $27-51 \mathrm{ng} / \mathrm{mL}$ for all cows) and did not change over time (Figure 1A). Concentrations of $25(\mathrm{OH}) \mathrm{D}$ were measured in samples of 2 of the 5 cows and were below the limit of detection $(5 \mathrm{ng} / \mathrm{mL})$ in quarters not treated with $25(\mathrm{OH}) \mathrm{D}$ but near that of serum in quarters treated with $25 \mathrm{D}$ and LPS $+25 \mathrm{D}$ at 4 $\mathrm{h}$ (Figure 1A). Rectal temperatures increased to $40.5^{\circ} \mathrm{C}$ on average within $4 \mathrm{~h}$ after the LPS challenge and were below $39^{\circ} \mathrm{C}$ by $12 \mathrm{~h}$ after challenge (Figure $1 \mathrm{~B}$ ).

The SCC in milk of LPS and LIPO+25D quarters was elevated $\left(7.24 \times 10^{6}\right.$ and $6.76 \times 10^{6}$ cells $\left./ \mathrm{mL}\right)$ compared with control and $25 \mathrm{D}$ quarters $\left(1.20 \times 10^{5}\right.$ and $2.24 \times 10^{5}$ cells $/ \mathrm{mL}$ ) at $12 \mathrm{~h}$ after treatment (main effect of LPS, $P<0.001$; Table 2; Figure 2A). The SCC of the 25D quarters tended $(P=0.09)$ to increase compared with control glands at $12 \mathrm{~h}$ (Table 2), but it did not differ between LIPO and LIPO+25D quarters. Overall, from 12 to $72 \mathrm{~h}$ postchallenge, the SCC in milk from 25D, LIPO, and LIPO+25D quarters was

A)

B)
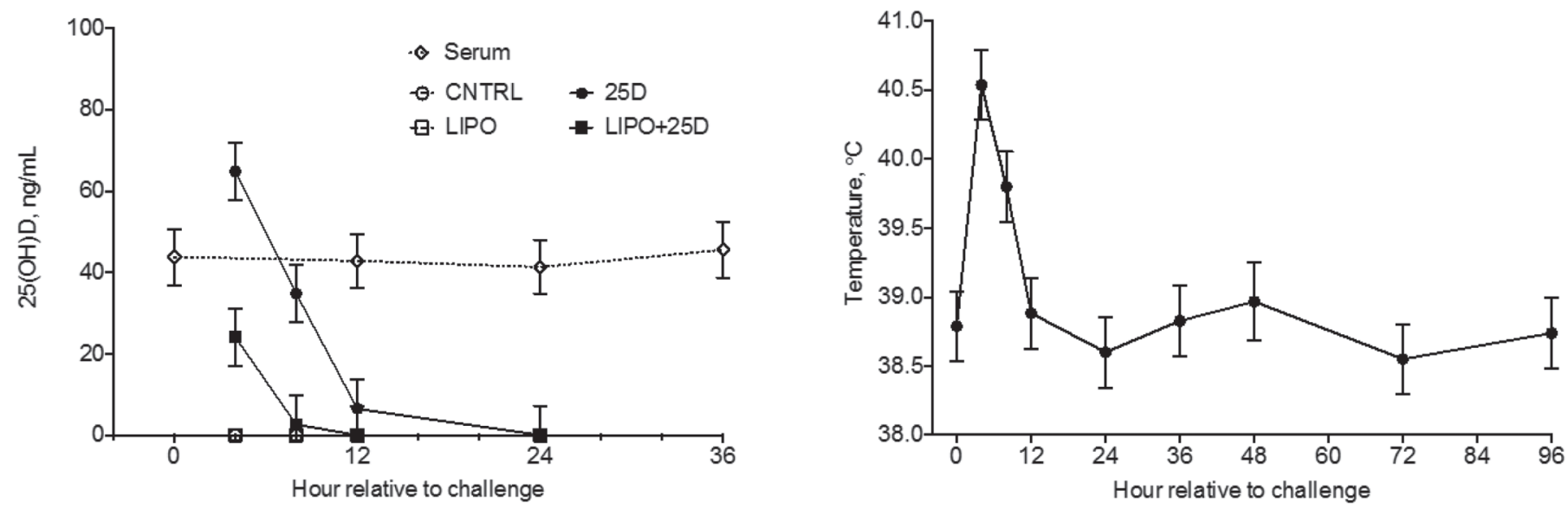

\section{C)}

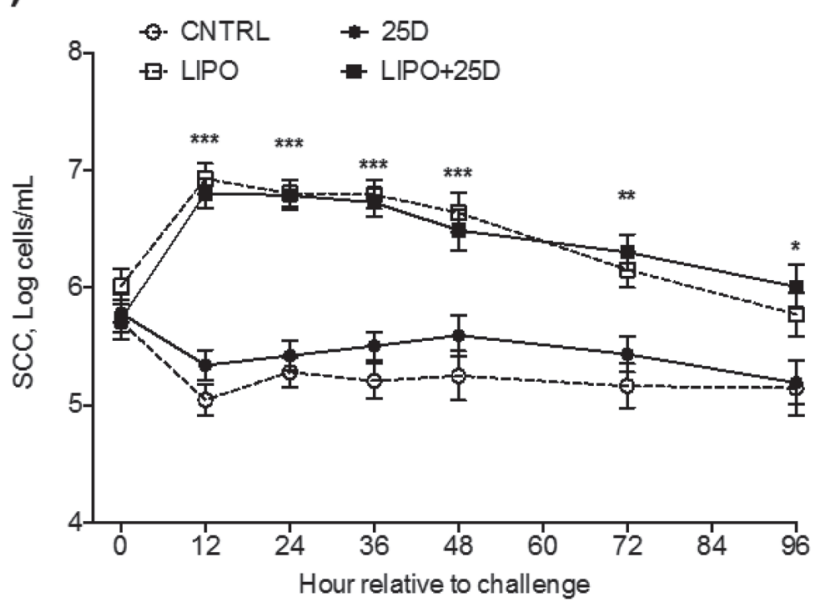

D)
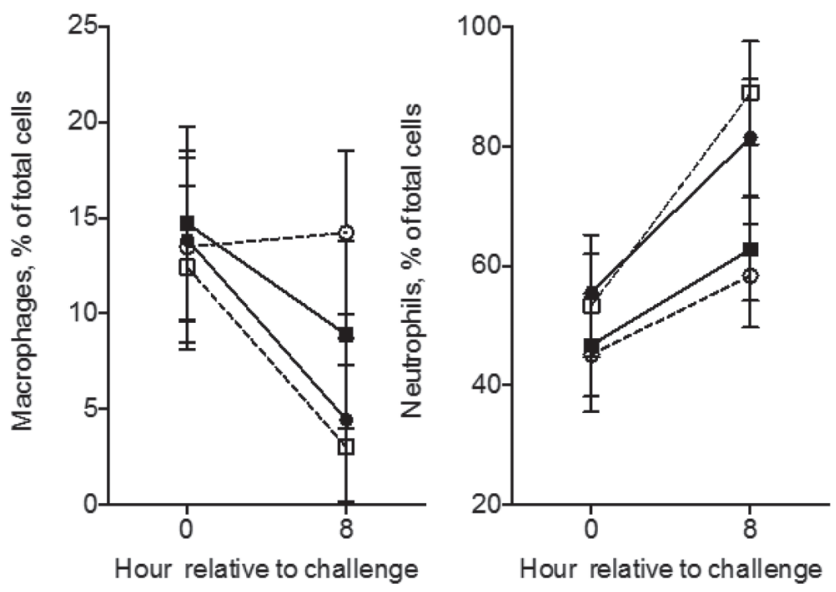

Figure 1. Least squares means \pm SEM of $(A)$ combined concentrations of $25(\mathrm{OH}) \mathrm{D} 2$ and $25(\mathrm{OH}) \mathrm{D} 3[25(\mathrm{OH}) \mathrm{D}]$ in serum or milk of treatment quarters, (B) rectal temperatures, (C) $\log _{10}$ of milk SCC, and (D) percentages of macrophages and neutrophils in milk of cows (n $=5$ ) treated intramammary with the control (CNTRL), $100 \mu \mathrm{g}$ of 25-hydroxyvitamin $\mathrm{D}_{3}(25 \mathrm{D}), 5 \mu \mathrm{g}$ of LPS (LIPO), or $5 \mu \mathrm{g}$ of LPS in combination with 100 $\mu \mathrm{g}$ of 25-hydroxyvitamin $\mathrm{D}_{3}(\mathrm{LIPO}+25 \mathrm{D})$. (A) Concentrations of $25(\mathrm{OH}) \mathrm{D}$ in milk represent data from 2 of 5 cows. Concentrations of $25(\mathrm{OH}) \mathrm{D}$ in milk of CNTRL and LIPO quarters were below limit of detection $(5 \mathrm{ng} / \mathrm{mL})$. (C) Means of LIPO and LIPO+25D quarters differed from those of CNTRL quarters $\left({ }^{*} P<0.05,{ }^{* *} P<0.01,{ }^{* * *} P<0.0001\right)$ at indicated time points. (D) Proportions of CD11b ${ }^{+} \mathrm{CD} 14^{+}$(macrophages) and

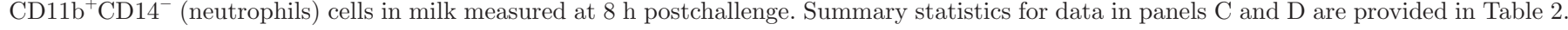


elevated $(P<0.01)$ compared with milk from control quarters (Figure 1B) but did not differ between LIPO and LIPO+25D quarters (Figure 1C).

The percentages of macrophages in milk at $8 \mathrm{~h}$ postchallenge were decreased in LIPO and LIPO $+25 \mathrm{D}$ quarters (4.6 and $2.9 \%$, respectively) compared with control and $25 \mathrm{D}$ quarters $(14.2$ and $8.7 \%$, respectively; LPS main effect, $P=0.005$; Table 2; Figure 1D), but percentages did not differ between control and 25D quarters or LIPO and LIPO+25D quarters. The percentages of neutrophils in milk at $8 \mathrm{~h}$ postchallenge (58.4, 82.1, 88.7, and $62.8 \%$ in control, 25D, LIPO, and LIPO $+25 \mathrm{D}$ quarters, respectively) were altered by treatments such that main effects of LPS and $25(\mathrm{OH})$ $\mathrm{D}_{3}$ treatments were not significant, but the interaction between LPS and $25(\mathrm{OH}) \mathrm{D}_{3}$ treatments was significant $(P=0.027$; Table 2; Figure 1D).

\section{Effects of Intramammary LPS and 25(OH) $D_{3}$ on Vitamin D Pathway Genes}

The LPS challenge induced a rapid upregulation of the vitamin $\mathrm{D}$ pathway genes in total somatic cells isolated from milk of LIPO and LIPO+25D quarters compared with the control. Transcripts for CYP27B1 and $V D R$ genes were upregulated in the LIPO and LIPO $+25 \mathrm{D}$ quarters compared with control and 25D quarters beginning at $4 \mathrm{~h}$ and remained elevated until 12 h $(P<0.001$; Table 3; Figure 2A). Maximum CYP27B1 expression was almost 90-fold greater in $\mathrm{LIPO}$ and $\mathrm{LIPO}+25 \mathrm{D}$ quarters at $8 \mathrm{~h}$ compared with baseline expression at $0 \mathrm{~h}$ (Figure 2A). Maximum $V D R$ expression was 6 -fold higher in LIPO and LIPO+25D quarters at $4 \mathrm{~h}$ compared with baseline at $0 \mathrm{~h}$ (Figure $2 \mathrm{~A})$. Expression of $C Y \mathrm{P}^{2} 4 A 1$ increased $(P<0.05)$ in milk somatic cells from 25D, LIPO, and LIPO+25D quarters compared with control quarters (Figure 2A). Overall, LPS and $25(\mathrm{OH}) \mathrm{D}_{3}$ treatments increased $(P$
$<0.05)$ expression of $C Y P 24 A 1$ in milk somatic cells (Table 3). A tendency $(P=0.06)$ for interaction between LPS and $25(\mathrm{OH}) \mathrm{D}_{3}$ treatments also was observed for CYP24A1 expression (Table 3).

For macrophage and neutrophil populations within milk somatic cells, LPS treatment upregulated $(P<$ 0.05) expression of $C Y P 27 B 1$ and $V D R$ in macrophages and neutrophils (Table 3; Figure 2B). Expression of CYP24A1 in macrophages and neutrophils from milk, however, was not altered by LPS and $25(\mathrm{OH}) \mathrm{D}_{3}$ treatments (Table 3; Figure 2B).

Compared with peripheral blood monocytes, $C Y$ P27B1, VDR, and CYP24A1 were greater $(P<0.01)$ in milk macrophages from LIPO glands at $8 \mathrm{~h}$ postchallenge (Figure 3A). Expression of $C Y P 27 B 1$ and $V D R$ also were greater $(P<0.01)$ in macrophages in milk compared with blood monocytes before LPS challenge (Figure 3A). Similarly, CYP27B1 and VDR transcripts were greater $(P<0.05)$ in milk neutrophils from LIPO quarters compared with blood neutrophils at $8 \mathrm{~h}$ postchallenge, but CYP24A1 in milk neutrophils did not differ from blood neutrophils (Figure 3B).

\section{Effects of Intramammary LPS and 25(OH) $D_{3}$ on Expression of Immune Genes}

All immune genes analyzed in milk somatic cells, except for DEFB5, were upregulated $(P<0.05)$ by LPS treatment (Table 3; Figure 4). Treatment with $25(\mathrm{OH}) \mathrm{D}_{3}$ did not influence expression of any of the immune genes in milk somatic cells (Table 3; Figure 4) except for $i N O S$, which tended to increase $(P=0.1)$ in $25 \mathrm{D}$ quarters compared with the control (Figure 4). Also, a tendency for the effect of interaction $(P=$ $0.08)$ between LPS and $25(\mathrm{OH}) \mathrm{D}_{3}$ treatments was observed for expression of $i N O S$ (Table 3). Expression of iNOS, DEFB3, DEFB4, DEFB7, and DEFB10 peaked from 8 to $12 \mathrm{~h}$ postchallenge, whereas that of $I L 1 B$

Table 2. Effect (means) of intramammary LPS and 25-hydroxyvitamin $\mathrm{D}_{3}$ on milk SCC and proportions of macrophages and neutrophils

\begin{tabular}{|c|c|c|c|c|c|c|c|c|}
\hline \multirow[b]{2}{*}{ Variable } & \multicolumn{4}{|c|}{ Treatment $^{1}$} & \multirow[b]{2}{*}{ SEM } & \multicolumn{3}{|c|}{$P$-value ${ }^{2}$} \\
\hline & Control & $25 \mathrm{D}$ & LIPO & $\mathrm{LIPO}+25 \mathrm{D}$ & & $25(\mathrm{OH}) \mathrm{D}_{3}$ & LPS & $\mathrm{LPS} \times 25(\mathrm{OH}) \mathrm{D}_{3}$ \\
\hline $\begin{array}{l}\text { SCC }{ }^{3} \log _{10} \text { cells } / \mathrm{mL} \\
\text { Macrophages, }{ }^{4} \% \\
\text { Neutrophils, }{ }^{4} \%\end{array}$ & $\begin{array}{l}5.08^{\mathrm{a}} \\
14.2^{\mathrm{a}} \\
58.4^{\mathrm{a}}\end{array}$ & $\begin{array}{r}5.35^{\mathrm{a}} \\
8.7^{\mathrm{ab}} \\
82.1^{\mathrm{ab}}\end{array}$ & $\begin{array}{l}6.86^{\mathrm{b}} \\
4.6^{\mathrm{b}} \\
88.7^{\mathrm{b}}\end{array}$ & $\begin{array}{l}6.83^{\mathrm{b}} \\
2.9^{\mathrm{b}} \\
62.8^{\mathrm{ab}}\end{array}$ & $\begin{array}{l}0.10 \\
2.4 \\
9.9\end{array}$ & $\begin{array}{l}0.178 \\
0.145 \\
0.907\end{array}$ & $\begin{array}{r}<0.001 \\
0.005 \\
0.590\end{array}$ & $\begin{array}{l}0.275 \\
0.418 \\
0.028\end{array}$ \\
\hline
\end{tabular}

\footnotetext{
${ }^{\mathrm{a}, \mathrm{b}}$ Means within a row with different letters are different $(P<0.05)$.

${ }^{1}$ Treatments: Control $=10 \mathrm{~mL}$ of PBS with $10 \%$ fetal bovine serum; $25 \mathrm{D}=100 \mu \mathrm{g}$ of 25 -hydroxyvitamin $\mathrm{D}_{3} ; \mathrm{LIPO}=5 \mu \mathrm{g}$ of LPS; LIPO+25D $=5 \mu \mathrm{g}$ of LPS plus $100 \mu \mathrm{g}$ of 25-hydroxyvitamin $\mathrm{D}_{3}$.

${ }^{2} 25(\mathrm{OH}) \mathrm{D}_{3}=$ effect of 25-hydroxyvitamin $\mathrm{D}_{3}$ (control and LIPO vs. $25 \mathrm{D}$ and LIPO $+25 \mathrm{D}$ ); LPS $=$ effect of LPS treatment (control and $25 \mathrm{D}$ vs. LIPO and LIPO $+25 \mathrm{D})$; LPS $\times 25(\mathrm{OH}) \mathrm{D}_{3}=$ interaction between LPS and 25-hydroxyvitamin $\mathrm{D}_{3}$ treatments (control and LIPO+25D vs. $25 \mathrm{D}$ and LIPO).

${ }^{3}$ Somatic cell counts in milk at $12 \mathrm{~h}$ postchallenge.

${ }^{4}$ Percentages of macrophages and neutrophils in milk measured at $8 \mathrm{~h}$ postchallenge.
} 
and IL 8 peaked at 4 to $8 \mathrm{~h}$ postchallenge in LIPO and LIPO+25D quarters (Figure 4). In contrast, expression of DEFB5 decreased $(P<0.05)$ at $4 \mathrm{~h}$ postchallenge in milk somatic cells from LIPO and LIPO+25D quarters (Figure 4).

Treatment with LPS increased $(P<0.001)$ expression of $i N O S$ and tended to increase expression of DEFB3, $D E F B 10$, and $I L 1 B$ in macrophages in milk somatic cells (Table 3). Expression of CCL5 in macrophages, on the other hand, was decreased $(P<0.05)$ by $25(\mathrm{OH}) \mathrm{D}_{3}$ treatment (Table 3 ; Figure 5). Treatment with LPS also upregulated $(P<0.05)$ iNOS, CCL5, DEFB3, DEFB4, $D E F B$ \%, DEFB10, and $I L 1 B$ in neutrophils from milk
(Table 3; Figure 5). Except for CCL5 in macrophages, the $25(\mathrm{OH}) \mathrm{D}_{3}$ treatment did not alter expression of the immune genes analyzed in macrophages or neutrophils, and no interactions were observed between LPS and $25(\mathrm{OH}) \mathrm{D}_{3}$ treatments (Table 3 ).

\section{Effects of Repeated Intramammary $25(\mathrm{OH}) \mathrm{D}_{3}$ in LPS-Challenged Quarters}

Expression of $C Y$ P2 $^{2} B 1$ in total milk somatic cells remained elevated $(P<0.05)$ in LIPO and LIPO+25D quarters compared with control quarters until $24 \mathrm{~h}$ postchallenge, whereas $V D R$ expression was not greater
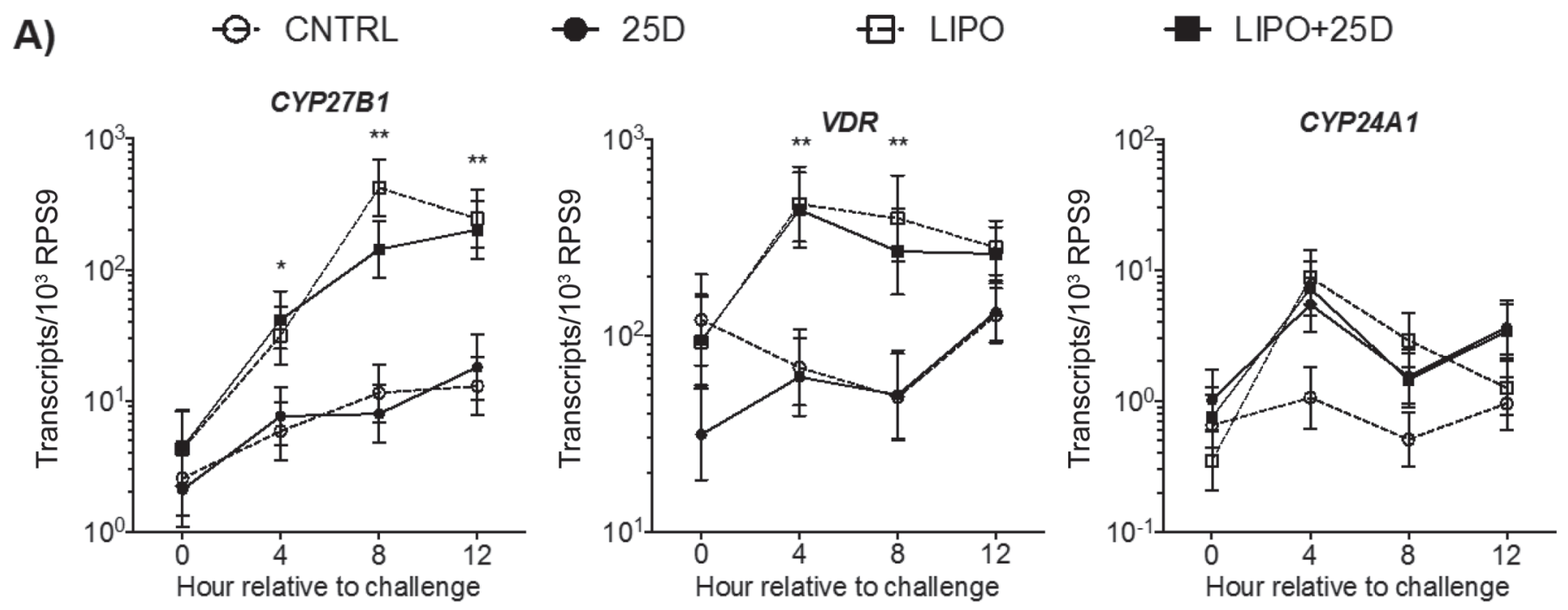

B)

25D

LIPO

VII LIPO+25D
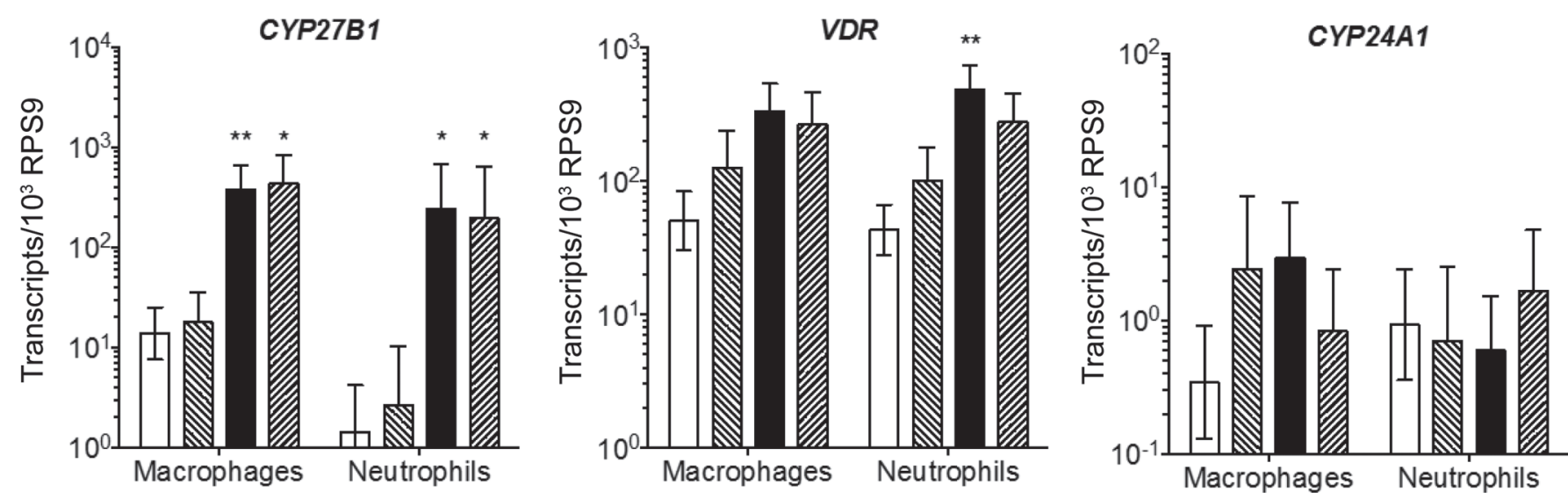

Figure 2. Abundance (LSM $\pm \mathrm{SEM}$ ) of transcripts for (A) vitamin D pathway genes $C Y P 27 B 1, V D R$, and $C Y P 24 A 1$ in total somatic cells and (B) macrophages and neutrophils from milk of glands treated with the control (CNTRL), $100 \mu \mathrm{g}$ of 25 -hydroxyvitamin $\mathrm{D}_{3}(25 \mathrm{D}), 5 \mu \mathrm{g}$ of LPS (LIPO), or $5 \mu \mathrm{g}$ of LPS in combination with $100 \mu \mathrm{g}$ of 25 -hydroxyvitamin $\mathrm{D}_{3}$ (LIPO+25D); $\mathrm{n}=5 /$ treatment. Transcript abundances are expressed relative to RPS9 transcript abundance. Macrophages and neutrophils were isolated at $8 \mathrm{~h}$ postchallenge. ${ }^{*} P<0.05,{ }^{* *} P<0.01,{ }^{* * *} P$ $<0.001$; relative transcript abundances in LIPO and LIPO+25D quarters differed from CNTRL. $P$-values for main effects of treatments and treatment interactions are provided in Table 3. 
in LIPO and LIPO+25D quarters compared with control quarters from 24 to $72 \mathrm{~h}$ (Figure 6). Expression of CYP24A1 in milk somatic cells did not differ between LIPO and control quarters from 12 to $72 \mathrm{~h}$ postchallenge, but it was greater $(P<0.01)$ in somatic cells of LIPO+25D quarters than in somatic cells of control or LIPO quarters (Figure 6). Expression of $i N O S$ in somatic cells from LIPO and LIPO $+25 \mathrm{D}$ quarters remained elevated $(P<0.05)$ at 24 and $36 \mathrm{~h}$ compared with the control but did not differ between LIPO and LIPO+25D quarters (Figure 6). The $\beta$-defensins, $C C L 5, I L 1 B$, and $I L 8$ genes were not elevated in LIPO or LIPO+25D quarters compared with control quarters from 24 to $72 \mathrm{~h}$ postchallenge, and none of the genes differed in $25 \mathrm{D}$ quarters compared with control quarters from 24 to $72 \mathrm{~h}$ (data not shown).

\section{DISCUSSION}

Understanding mechanisms that control immune responses in the mammary gland is necessary to improve treatment and prevention strategies for mastitis in dairy cows. Previous reports have demonstrated that vitamin D pathway signaling (CYP27B1, VDR, and $C Y P 24 A 1)$ is upregulated in the mammary gland during S. uberis mastitis (Nelson et al., 2010a) and that intramammary $25(\mathrm{OH}) \mathrm{D}_{3}$ treatment inhibited $S$. uberis mastitis in dairy cattle (Lippolis et al., 2011). Here, we observed that vitamin D pathway signaling was rap- idly induced by the innate response to intramammary LPS challenge. Although intramammary $25(\mathrm{OH}) \mathrm{D}_{3}$ modulated milk SCC and proportion of neutrophils in milk, $25(\mathrm{OH}) \mathrm{D}_{3}$ did not influence expression of immune genes in the same way as in LPS-stimulated monocyte cultures (Nelson et al., 2010b; Merriman et al., 2015). This information aids in understanding the dynamics of vitamin D signaling during the innate immune response to bacterial endotoxins.

The LPS challenge induced a large increase in expression of $C Y$ P27B1, the gene that encodes for the 25-hydroxyvitamin D 1 $\alpha$-hydroxylase, in milk macrophages and neutrophils. Induction of vitamin D pathway signaling in macrophages via toll-like receptor recognition of bacterial associated molecules such as LPS has been demonstrated using in vitro cultures of monocytes and macrophages (Liu et al., 2006; Nelson et al., 2010b). Recognition of LPS via the CD14/TLR4 receptor complex activates mitogen-activated protein kinase and nuclear factor $\mathrm{\kappa B}$ signaling pathways, which have been implicated in the induction of $C Y P^{2} 7 B 1$ transcription (Stoffels et al., 2006). The relative abundance of $C Y$ P27B1 transcripts was similar between macrophages and neutrophils upon LPS stimulation, unlike the predominant expression of $C Y P^{2} 7 B 1$ in macrophages previously reported for $S$. uberis mastitis (Nelson et al., 2010a). Neutrophils make up almost $90 \%$ of total somatic cells during mastitis and therefore potentially are a major contributor to $1,25(\mathrm{OH})_{2} \mathrm{D}_{3}$ synthesis in

Table 3. Effect of intramammary LPS and 25-hydroxyvitamin $\mathrm{D}_{3}$ on gene expression in milk somatic cells, macrophages, and neutrophils ${ }^{1}$

\begin{tabular}{|c|c|c|c|c|c|c|c|c|c|}
\hline Gene $^{2}$ & \multicolumn{3}{|c|}{ Total cells ${ }^{3}$} & \multicolumn{3}{|c|}{ Macrophages $^{4}$} & \multicolumn{3}{|c|}{ Neutrophils ${ }^{4}$} \\
\hline$C Y P_{27 B 1}$ & $<0.001$ & 0.400 & 0.853 & 0.003 & 0.759 & 0.917 & 0.002 & 0.864 & 0.727 \\
\hline$C Y{ }^{24} 41$ & 0.048 & 0.049 & 0.057 & 0.622 & 0.760 & 0.181 & 0.848 & 0.737 & 0.573 \\
\hline$i N O S$ & $<0.001$ & 0.562 & 0.081 & 0.006 & 0.307 & 0.904 & $<0.001$ & 0.287 & 0.603 \\
\hline$C C L 5$ & 0.001 & 0.940 & 0.640 & 0.702 & 0.028 & 0.522 & 0.002 & 0.772 & 0.767 \\
\hline$D E F B 5$ & 0.930 & 0.827 & 0.763 & 0.895 & 0.765 & 0.401 & 0.156 & 0.856 & 0.982 \\
\hline$D E F B 7$ & 0.005 & 0.924 & 0.747 & 0.101 & 0.628 & 0.744 & 0.001 & 0.337 & 0.452 \\
\hline DEFB10 & 0.004 & 0.610 & 0.748 & 0.077 & 0.924 & 0.595 & $<0.001$ & 0.963 & 0.473 \\
\hline$I L 1 B$ & $<0.001$ & 0.907 & 0.749 & 0.066 & 0.827 & 0.417 & $<0.001$ & 0.246 & 0.959 \\
\hline$I L 8$ & $<0.001$ & 0.859 & 0.728 & 0.272 & 0.728 & 0.098 & 0.149 & 0.886 & 0.947 \\
\hline
\end{tabular}

${ }^{1}$ Values represent $P$-values for effects of treatments on abundances of listed transcripts. Treatments: Control $=10 \mathrm{~mL}$ of PBS with $10 \%$ fetal bovine serum; $25 \mathrm{D}=100 \mu \mathrm{g}$ of 25 -hydroxyvitamin $\mathrm{D}_{3} ; \mathrm{LIPO}=5 \mu \mathrm{g}$ of LPS; LIPO $+25 \mathrm{D}=5 \mu \mathrm{g}$ of LPS plus $100 \mu \mathrm{g}$ of 25 -hydroxyvitamin $\mathrm{D}_{3}$. $25(\mathrm{OH}) \mathrm{D}_{3}=$ effect of 25-hydroxyvitamin $\mathrm{D}_{3}$ (control and LIPO vs. $25 \mathrm{D}$ and LIPO+25D); LPS $=$ effect of LPS treatment (control and $25 \mathrm{D}$ vs. LIPO and LIPO $+25 \mathrm{D})$; LPS $\times 25(\mathrm{OH}) \mathrm{D}_{3}=$ interaction between LPS and 25-hydroxyvitamin $\mathrm{D}_{3}$ treatments (control and LIPO+25D vs. 25D and LIPO).

${ }^{2}$ Transcripts for 25-hydroxyvitamin D 1 $\alpha$-hydroxylase (CYP27B1), 25-hydroxyvitamin D 24-hydroxylase (CYP24A1), vitamin D receptor $(V D R)$, inducible nitric oxide synthase ( $N O S$ ), chemokine (C-C motif) ligand 5 (CCL5), bovine $\beta$-defensins (DEFB3, DEFB4, DEFB5, DEFB7, $D E F B 10)$, IL-1 $\beta(I L 1 B)$, and IL-8 (IL8) were measured by quantitative real-time PCR.

${ }^{3}$ Comparison of gene expression in total somatic cells isolated from milk sampled at 4,8 , and $12 \mathrm{~h}$ postchallenge.

${ }^{4}$ Comparison of gene expression in macrophages and neutrophils isolated from milk sampled at $8 \mathrm{~h}$ postchallenge. 

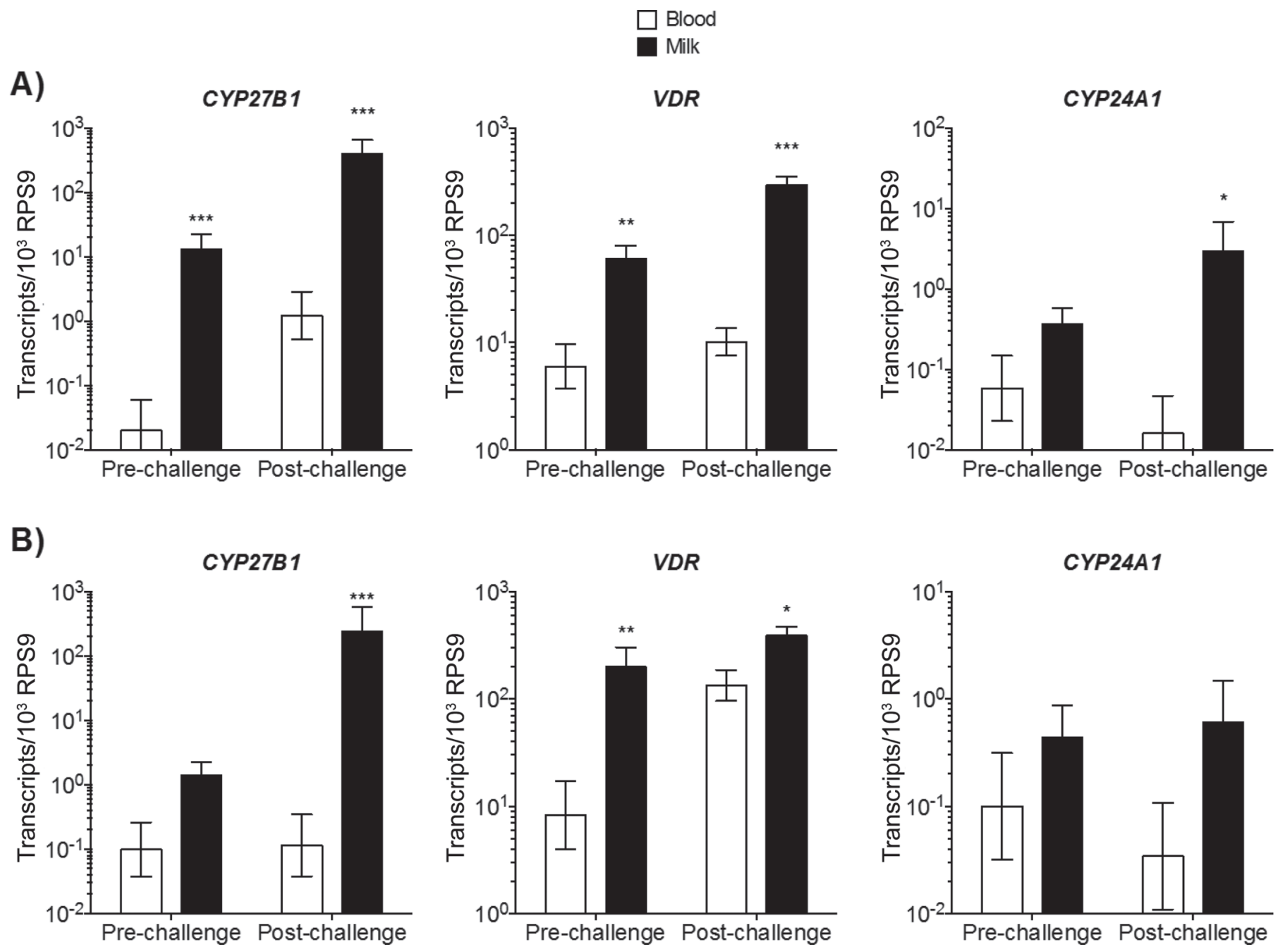

Figure 3. Abundance (LSM $\pm \mathrm{SEM}$ ) of transcripts for vitamin D pathway genes $C Y P 27 B 1, V D R$, and $C Y P 24 A 1$ in (A) monocytes or milk macrophages and (B) neutrophils from peripheral blood or milk of quarters that received intramammary LPS ( $\mathrm{n}=5 /$ treatment). Samples were collected at $0 \mathrm{~h}$ (prechallenge) or $8 \mathrm{~h}$ (postchallenge) relative to LPS challenge. ${ }^{*} P<0.05,{ }^{* *} P<0.01$, ${ }^{* * *} P<0.001$; relative transcript abundances in milk cells differed from blood cells.

the mammary gland during the early innate immune response to bacteria.

The simultaneous induction of VDR by LPS stimulation is presumed to amplify the effects of $1,25(\mathrm{OH})_{2} \mathrm{D}_{3}$ synthesis. Many cells of the body express the VDR (Norman, 2008), but the factors contributing to VDR expression are not completely understood. Upregulation of $V D R$ expression in response to LPS highlights the potential importance of $1,25(\mathrm{OH})_{2} \mathrm{D}_{3}$ on immune regulation and, together with $C Y P^{2} 7 B 1$, provides further support that induction of the vitamin D pathway is an integral component of the innate immune response. Notably, $C Y P^{2} 7 B 1$ and $V D R$ transcripts also were greater in milk macrophages compared with blood monocytes before the challenge and in glands not treated with LPS. The baseline level of $C Y P 27 B 1 \mathrm{ex}-$ pression in resident macrophages of the gland suggests that some $1,25(\mathrm{OH})_{2} \mathrm{D}_{3}$ synthesis may occur as part of the homeostatic function of tissue macrophages.

The increase of CYP24A1 expression in response to LPS and $25(\mathrm{OH}) \mathrm{D}_{3}$ treatments in the present experiment indicates probable function of CYP27B1 and VDR in the mammary gland. The CYP24A1 encodes for the 25-hydroxyvitamin D 24-hydroxylase, which provides feedback control of vitamin $\mathrm{D}$ signaling by metabolizing $25(\mathrm{OH}) \mathrm{D}_{3}$ and $1,25(\mathrm{OH})_{2} \mathrm{D}_{3}$ to inactive metabolites (Reinhardt et al., 1999). The CYP24A1 promoter contains several VDR binding sites (Meyer et al., 2010), and it was strongly induced by $1,25(\mathrm{OH})_{2} \mathrm{D}_{3}$ in monocytes, neutrophils, and mammary 
epithelial cells (Merriman et al., 2015). Intramammary $1,25(\mathrm{OH})_{2} \mathrm{D}_{3}$ treatment also induced a massive increase of CYP24A1 expression in milk somatic cells (Merriman et al., 2017). In the present experiment, expression of CYP24A1 was increased by LPS and $25(\mathrm{OH}) \mathrm{D}_{3}$ treatments in total somatic cells within the first $4 \mathrm{~h}$. We
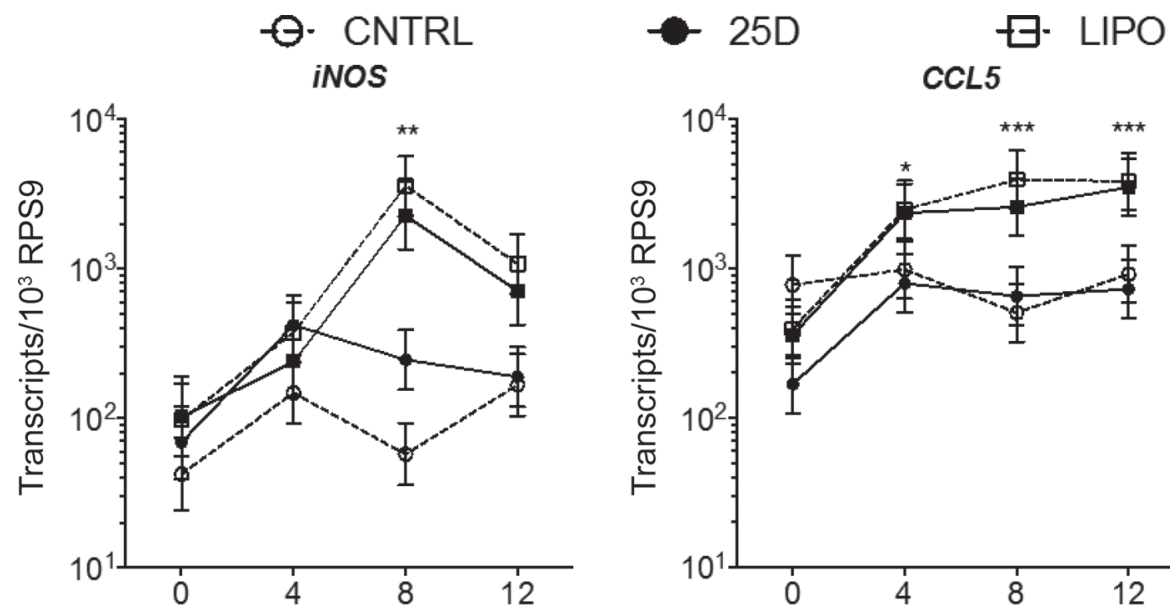

-7 LIPO+25D
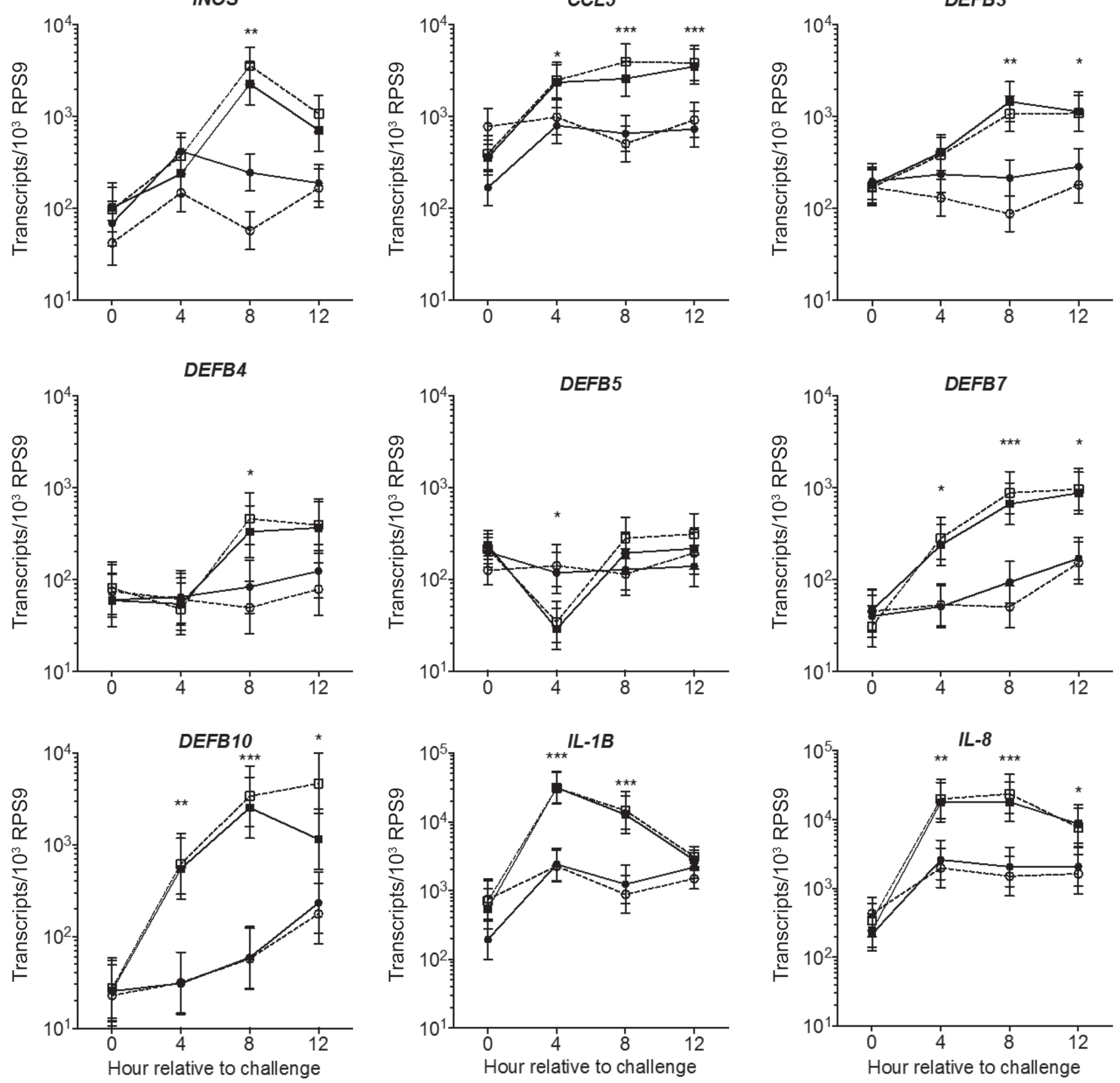

Figure 4. Abundance (LSM \pm SEM) of transcripts for inducible nitric oxide synthase (iNOS), chemokine (C-C motif) ligand 5 (CCL5), 3-defensin (DEFB) 3, DEFB4, DEFB5, DEFB7, DEFB10, IL-13 (IL1B), and IL-8 (IL8) in total somatic cells from milk of quarters treated with the control (CNTRL), $100 \mu \mathrm{g}$ of 25 -hydroxyvitamin $\mathrm{D}_{3}$ (25D), $5 \mu \mathrm{g}$ of lipopolysaccharide (LIPO), and $5 \mu \mathrm{g}$ of LPS in combination with $100 \mu \mathrm{g}$ of 25-hydroxyvitamin $\mathrm{D}_{3}(\mathrm{LIPO}+25 \mathrm{D}) ; \mathrm{n}=5$ /treatment. Transcript abundances are expressed relative to $R P S 9$ transcript abundance. ${ }^{*} P<$ $0.05,{ }^{* *} P<0.01,{ }^{* * *} P<0.001$; relative transcript abundances in LPS (LIPO and LIPO+25D) quarters differed from non-LPS (CNTRL and 25D) quarters. $P$-values for main effects of treatments and treatment interactions are provided in Table 3. 
speculate that the increase in $C Y P 24 A 1$ resulted from increased conversion of $25(\mathrm{OH}) \mathrm{D}_{3}$ to $1,25(\mathrm{OH})_{2} \mathrm{D}_{3}$ by CYP27B1 in macrophages in neutrophils. Conclusive evidence of $1,25(\mathrm{OH}) \mathrm{D}_{3}$ synthesis, however, is limited because accurate measurement of $1,25(\mathrm{OH}) \mathrm{D}_{3}$ in milk is not feasible.
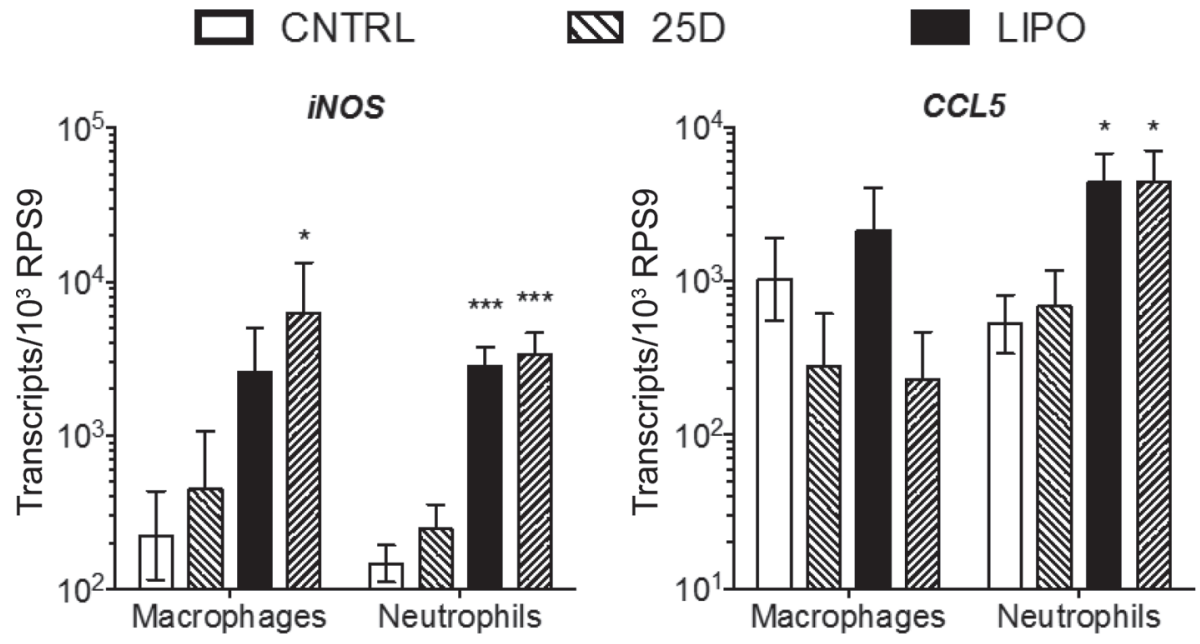

WII LIPO+25D
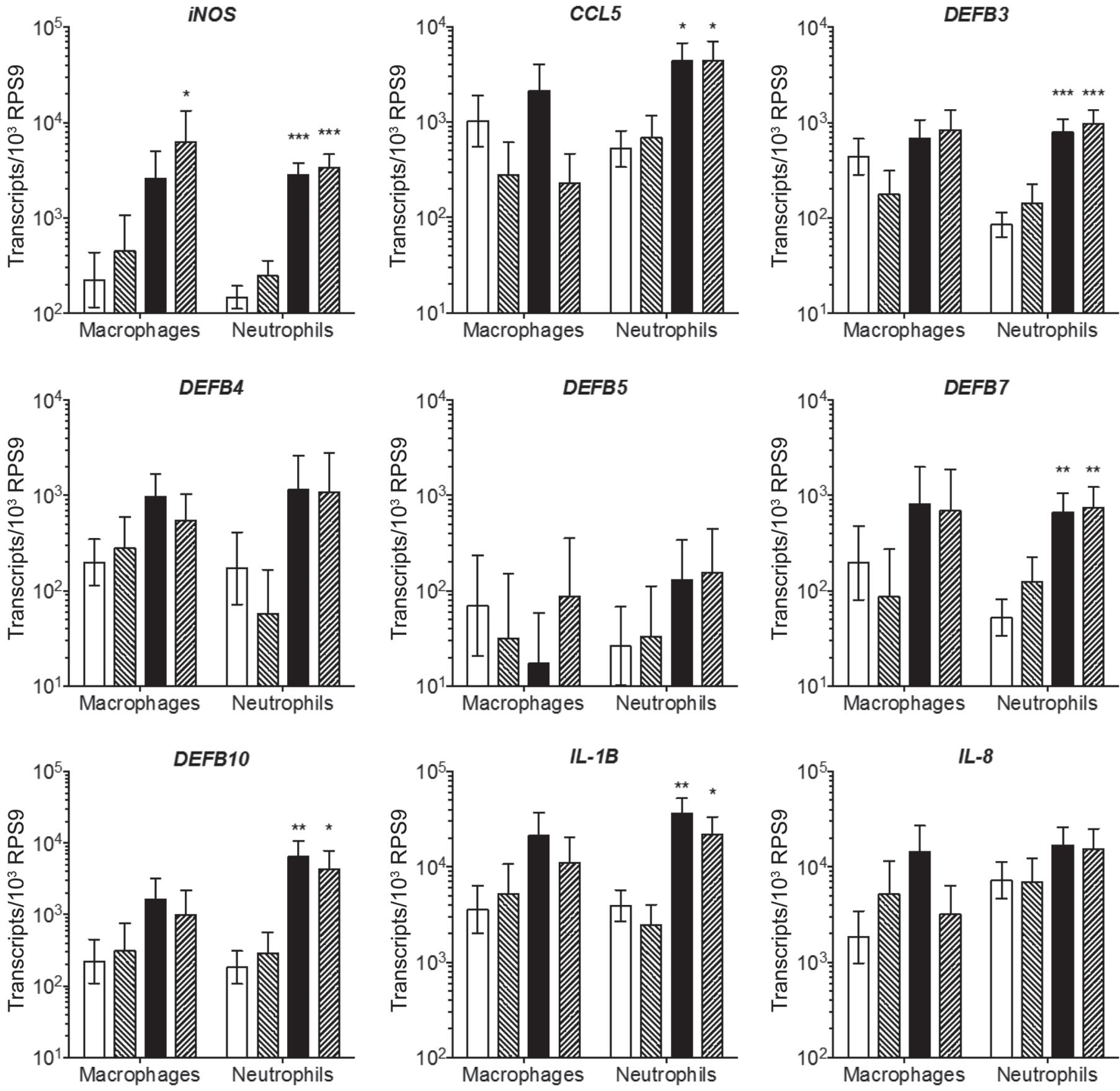

Figure 5. Abundance (LSM $\pm \mathrm{SEM}$ ) of transcripts for inducible nitric oxide synthase (iNOS), chemokine (C-C motif) ligand 5 (CCL5), 3-defensin (DEFB) 3, DEFB4, DEFB5, DEFB7, DEFB10, IL-13 (IL1B), and IL-8 (IL8) in CD11b ${ }^{+}$CD14 ${ }^{+}$(macrophages) and CD11b ${ }^{+}$CD14 (neutrophils) cells from milk of quarters treated with the control (CNTRL), $100 \mu \mathrm{g}$ of 25-hydroxyvitamin $\mathrm{D}_{3}$ (25D), $5 \mu \mathrm{g}$ of lipopolysaccharide (LIPO), and $5 \mu \mathrm{g}$ of LPS in combination with $100 \mu \mathrm{g}$ of 25 -hydroxyvitamin $\mathrm{D}_{3}$ (LIPO+25D); $\mathrm{n}=5$ /treatment. Transcript abundances are expressed relative to RPS9 transcript abundance at 8 h postchallenge. ${ }^{*} P<0.05$, ${ }^{* *} P<0.01$, ${ }^{* * *} P<0.001$; relative transcript abundances differed from CNTRL. $P$-values for main effects of treatments and treatment interactions are provided in Table 3. 
We anticipated that intramammary $25(\mathrm{OH}) \mathrm{D}_{3}$ treatment in combination with LPS would increase CYP24A1 compared with LPS alone because of increased substrate for CYP27B1. Although treatment with $25(\mathrm{OH}) \mathrm{D}_{3}$ increased $C Y P 24 A 1$ in milk somatic cells overall, expression of $C Y P 24 A 1$ was not greater in LIPO+25D glands compared with LIPO glands within the first $12 \mathrm{~h}$ after challenge. In contrast, CYP24A1 increased in 25D glands compared with control glands. Also, CYP24A1 was greater in LIPO+25D glands compared LIPO glands from 12 to $36 \mathrm{~h}$ when the acute response was subsiding. The lack of CYP24A1 response to $25(\mathrm{OH}) \mathrm{D}_{3}$ in combination with LPS treatment may be attributed to inhibitory effects of LPS stimulation on induction of $C Y P 24 A 1$ expression by $1,25(\mathrm{OH})_{2} \mathrm{D}_{3}$ (Nelson et al., 2010b). The antagonistic effect of LPS on CYP24A1 expression is further supported by a tendency for interaction between $25(\mathrm{OH}) \mathrm{D}_{3}$ and LPS treatments on CYP24A1 expression in milk somatic cells. Interaction between the VDR and other intracel- lular pathways activated by TLR signaling has been reported (Vidal et al., 2002; Sadeghi et al., 2006) and potentially explains the antagonistic effect of LPS on $C Y P 24 A 1$ expression. Taken together, we propose that the induction of $C Y$ P2 $4 A 1$ expression in milk somatic cells by LPS treatment occurred because of increased CYP27B1 and VDR activity; however, no additional increase in CYP24A1 expression was achieved by the combination of $25(\mathrm{OH}) \mathrm{D}_{3}$ and LPS treatments because of the antagonistic effect of LPS on CYP24A1 expression.

Intramammary $25(\mathrm{OH}) \mathrm{D}_{3}$ treatment increased milk SCC in non-LPS glands and altered the proportions of neutrophils in milk. In comparison, milk SCC did not increase with intramammary $1,25(\mathrm{OH})_{2} \mathrm{D}_{3}$ treatment in healthy glands but tended to increase with $1,25(\mathrm{OH})_{2} \mathrm{D}_{3}$ in subclinically infected glands (Merriman et al., 2017). Although an interaction between LPS and $25(\mathrm{OH}) \mathrm{D}_{3}$ treatments was observed for proportions of neutrophils in milk at $8 \mathrm{~h}$ postchallenge in this experi-

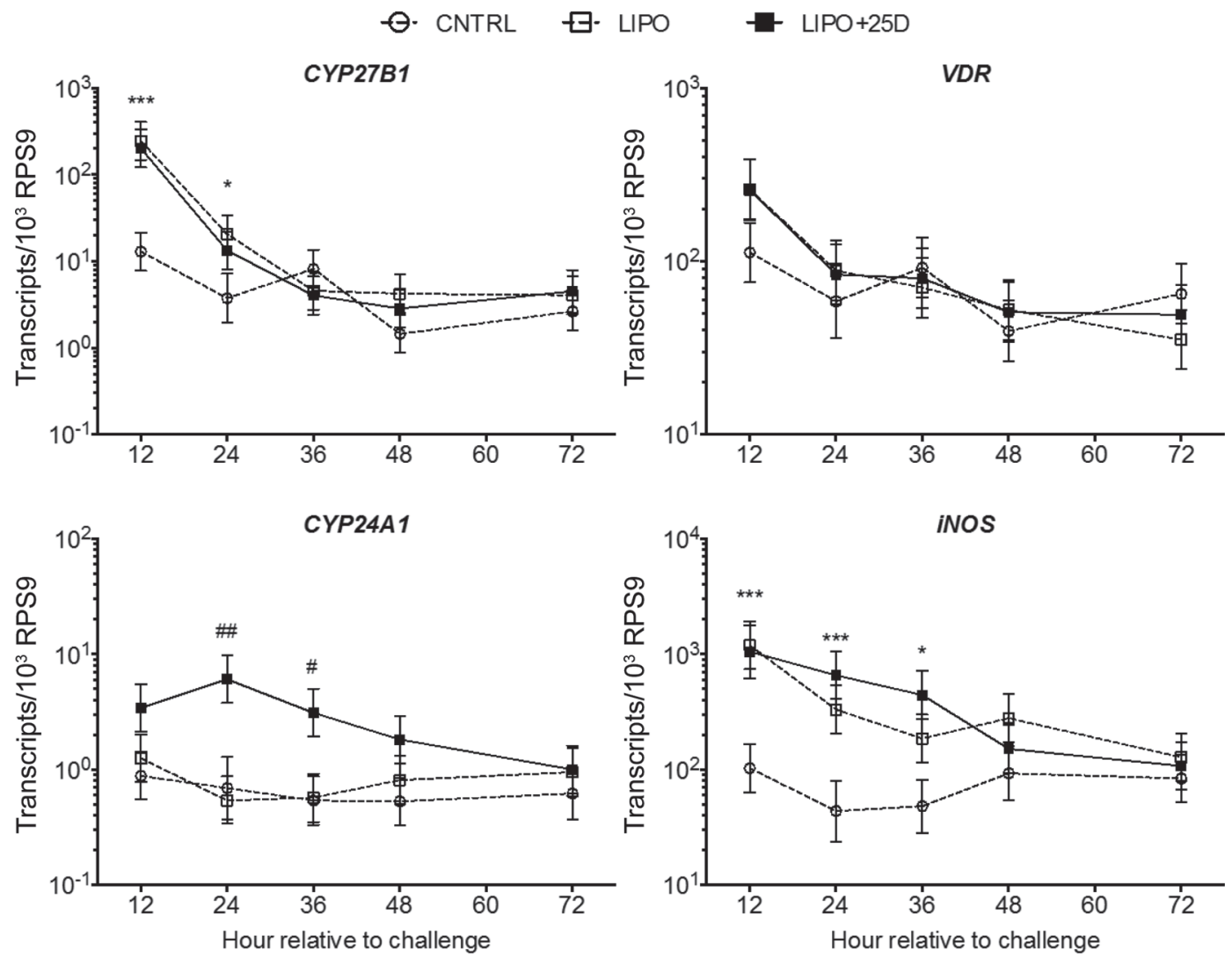

Figure 6. Abundance (LSM $\pm \mathrm{SEM}$ ) of transcripts for vitamin D pathway genes (CYP27B1, VDR, and CYP24A1) and inducible nitric oxide synthase $(i N O S)$ in total somatic cells from milk of quarters at 12 to $72 \mathrm{~h}$ after treatment with the control (CNTRL), $5 \mu \mathrm{g}$ of LPS (LIPO), and $5 \mu \mathrm{g}$ of LPS in combination with $100 \mu \mathrm{g}$ of 25 -hydroxyvitamin $\mathrm{D}_{3}(\mathrm{LIPO}+25 \mathrm{D})$ intramammary treatments; $\mathrm{n}=5 /$ treatment. The LIPO $+25 \mathrm{D}$ quarters received repeated injections of $100 \mu \mathrm{g}$ of 25 -hydroxyvitamin $\mathrm{D}_{3}$ at 12,24 , and $36 \mathrm{~h}$ postchallenge and were compared with CNTRL and LIPO quarters. Transcript abundance is expressed relative to $R P S 9$. ${ }^{*} P<0.05$, ${ }^{* *} P<0.01$, $* * * P<0.001$; relative transcript abundance in LIPO and LIPO+25D quarters differed from CNTRL. \#P<0.05, \#\#P<0.01; relative transcript abundance in LIPO+25D glands differed from LIPO quarters. 
ment, the effect of treatments on neutrophil counts in milk is unknown because cell counts were not measured at $8 \mathrm{~h}$ postchallenge. Additionally, cells were considered neutrophils if they were $\mathrm{CD} 11 \mathrm{~b}^{+} \mathrm{CD} 14^{-}$, so the treatment interaction observed could instead be interpreted as a change in cell phenotype rather than a change in relative abundance of neutrophils. In either case, the effects of intramammary $25(\mathrm{OH}) \mathrm{D}_{3}$ treatment on milk SCC warrant further investigation on the role of vitamin D signaling in immune cell trafficking to the mammary gland.

We anticipated that intramammary $25(\mathrm{OH}) \mathrm{D}_{3}$ treatment would boost expression of iNOS, CCL5, and $\beta$-defensin genes in milk somatic cells because each of these genes increased with $25(\mathrm{OH}) \mathrm{D}_{3}$ treatment in LPS-stimulated cultures of peripheral blood monocytes (Nelson et al., 2010b; Merriman et al., 2015). Furthermore, intramammary $1,25(\mathrm{OH})_{2} \mathrm{D}_{3}$ treatment increased expression of $i N O S, D E F B 4$, and DEFB7 in milk somatic cells (Merriman et al., 2017) and macrophages, and on the basis of CYP27B1 expression in the present study, neutrophils likely had the ability to convert $25(\mathrm{OH}) \mathrm{D}_{3}$ to $1,25(\mathrm{OH})_{2} \mathrm{D}_{3}$. Conversely, $i N O S$ and $\beta$-defensin expression did not increase in LIPO $+25 \mathrm{D}$ glands compared with LIPO glands, possibly because the strong acute response to LPS overwhelmed any influence of the vitamin D signal. In addition, contrary to the effects of $25(\mathrm{OH}) \mathrm{D}_{3}$ in LPS-stimulated monocytes (Nelson et al., 2010b), expression of CCL5 decreased with $25(\mathrm{OH}) \mathrm{D}_{3}$ in macrophages. These observations underscore the context and cell-specific responses elicited by vitamin $\mathrm{D}$ signaling but do not rule out the influence of vitamin D signaling on expression of $i N O S$ and $\beta$-defensin genes.

The challenge model used in the present experiment differed from that used by Lippolis et al. (2011), who showed that intramammary $25(\mathrm{OH}) \mathrm{D}_{3}$ treatment reduced the severity of $S$. uberis mastitis. Inflammatory responses did not develop until 48 to $72 \mathrm{~h}$ postchallenge in the challenge model used by Lippolis et al. (2011) compared with 4 to $8 \mathrm{~h}$ in the present LPS challenge model. Furthermore, the $100 \mu \mathrm{g}$ of $25(\mathrm{OH}) \mathrm{D}_{3}$ treatments in the experiment reported by Lippolis et al. (2011) were administered daily starting concurrent with the bacterial challenge, before initiation of inflammation of the mammary glands. As observed here, resident macrophages of the healthy mammary gland have increased CYP27B1 expression compared with blood monocytes, which indicates the potential ability to convert $25(\mathrm{OH}) \mathrm{D}_{3}$ to $1,25(\mathrm{OH})_{2} \mathrm{D}_{3}$. Indeed, the intramammary $25(\mathrm{OH}) \mathrm{D}_{3}$ treatment increased $i N O S$ in milk somatic cells independent of LPS in this experiment. Thus, the influence of $25(\mathrm{OH}) \mathrm{D}_{3}$ in noninflammatory conditions may be quite different than when acute in- flammatory conditions are induced by LPS or other inflammatory mediators.

One consideration of this experiment is that the cows received approximately 40,000 IU of dietary vitamin $\mathrm{D}_{3}$. Dairy cows fed similar amounts of vitamin $\mathrm{D}_{3}$ in similar conditions typically have serum $25(\mathrm{OH}) \mathrm{D}_{3}$ concentrations between 40 and $100 \mathrm{ng} / \mathrm{mL}$ (Nelson et al., 2016a). Serum 25(OH)D concentrations of cows in this experiment were $43 \mathrm{ng} / \mathrm{mL}$ on average, which is arguably sufficient for support of vitamin D-dependent functions of the immune system. Concentrations of $25(\mathrm{OH}) \mathrm{D}_{3}$ in milk are typically below $0.5 \mathrm{ng} / \mathrm{mL}$ and poorly correlated with $25(\mathrm{OH}) \mathrm{D}$ concentrations in serum (McDermott et al., 1985). In this experiment, milk $25(\mathrm{OH}) \mathrm{D}$ concentrations were below the limit of detection $(5 \mathrm{ng} / \mathrm{mL})$ in samples from quarters not treated with $25(\mathrm{OH}) \mathrm{D}_{3}$. Intramammary treatment with $100 \mu \mathrm{g}$ of $25(\mathrm{OH}) \mathrm{D}_{3}$ increased milk $25(\mathrm{OH}) \mathrm{D}_{3}$ concentrations to values near that of serum; however, the amount or route of $25(\mathrm{OH}) \mathrm{D}_{3}$ injected may not have adequately increased intracellular $25(\mathrm{OH}) \mathrm{D}_{3}$ concentrations to elicit an observable change in expression of immune genes that were measured.

Another important consideration of the experimental design implemented is that mammary gland within cow was the experimental unit. Systemic changes were observed in cows over the course of the experiment. It is possible that LPS treatments might have influenced responses in glands not treated with LPS. Nevertheless, by using gland within cow as the experimental unit, we minimized the variability among experimental units at the same time that we controlled for the random effect of cow. By default, it is assumed that glands from the same cow are more alike than glands from different cows. Therefore, the current approach used likely improved the precision of the experiment, although it is possible that systemic effects of a treatment might have influenced response to another treatment within the same cow. Other considerations of the experiment were the number of cows used and the timing and methods of sample collections. The number of cows used was the minimum needed to detect changes in gene expression on the basis of power analysis using data from previous experiments, so effects of treatments may have been undetected because the minimum number of cows was used. In regards to sample collections, collection of sequential aliquots of milk from each quarter at each time point for total somatic cell and sorted cell gene expression potentially gives rise to heterogeneous populations of cells for the subsequent assays performed because concentrations of leukocytes in milk are not homogeneous among fractions of milk collected from the same quarter. The cooling of milk samples and simple centrifugation procedure we used for isolation of cells 
was to facilitate rapid collection of cells and limit cell degradation, but it comes at the expense of extraction efficiency and failure to collect a full representation of immune cells secreted in the milk. Indeed, much of the activity of the vitamin D pathway may be taking place in neutrophils and macrophages present in the alveolar lumen or extravagating the mammary epithelium.

A secondary goal of this experiment was to determine the dynamics of $\beta$-defensin gene expression in response to LPS challenge. Expression of DEFB3, DEFB4, $D E F B 5$, and DEFB10 has been documented in infected (Kościuczuk et al., 2014) and healthy (Tetens et al., 2010) bovine mammary glands. Lipopolysaccharide treatment induced expression of several $\beta$-defensins in mammary epithelial cell and neutrophil cultures (Merriman et al., 2015), but the dynamics and factors controlling their expression in the mammary gland were not known. We observed that LPS stimulated DEFB3, $D E F B 4, D E F B 7$, and DEFB10 in somatic cells within several hours after challenge. In agreement with in vitro experiments, the response of the $\beta$-defensins to intramammary LPS also was more dramatic in neutrophils compared with macrophages (Merriman et al., 2015). Although not shown, similar results were observed for expression of the gene for lingual antimicrobial peptide, another member of the bovine chromosome $27 \beta$-defensin gene family, which also was induced by intramammary LPS challenge in a previous experiment (Isobe et al., 2009). Expression of DEFB5, on the other hand, decreased at $4 \mathrm{~h}$ after LPS challenge, which is similar to the response of monocytes but contrary to the response of mammary epithelial cells and neutrophil cultures (Merriman et al., 2015). Of the $\beta$-defensin genes, the response of $D E F B 10$ was most dramatic, increasing more than 200-fold compared with baseline expression. The DEFB10 peptide also was the most abundant $\beta$-defensin peptide in milk fat globules from glands infected with Staphylococcus aureus (Reinhardt et al., 2013), highlighting the potential significance in defense against bacterial infection of the mammary gland.

\section{CONCLUSIONS}

Immune cells of the mammary gland are capable of converting $25(\mathrm{OH}) \mathrm{D}_{3}$ to $1,25(\mathrm{OH})_{2} \mathrm{D}_{3}$ as indicated by elevated $C Y$ P2 $^{2} B 1$ transcript abundance and changes in $1,25(\mathrm{OH})_{2} \mathrm{D}_{3}$-inducible genes in response to intramammary $25(\mathrm{OH}) \mathrm{D}_{3}$ treatment. The innate immune response to intramammary endotoxin challenge increases vitamin D signaling in mammary immune cells and, although effects of intramammary $25(\mathrm{OH}) \mathrm{D}_{3}$ treatment were modest, the outcomes of this experiment indicate that availability of $25(\mathrm{OH}) \mathrm{D}_{3}$ for synthesis of
$1,25(\mathrm{OH})_{2} \mathrm{D}_{3}$ in mammary immune cells alters mammary immune responses. Intramammary $25(\mathrm{OH}) \mathrm{D}_{3}$ treatment may not dramatically influence the acute response to endotoxin-induced mastitis; however, harnessing the immunomodulatory effects of vitamin D signaling in immune cells via dietary or therapeutic manipulation of $25(\mathrm{OH}) \mathrm{D}_{3}$ availability may provide an opportunity to improve protection of the mammary gland from bacterial infections.

\section{ACKNOWLEDGMENTS}

The authors thank Monika Trejos and Emily Wilkes (University of Florida, Gainesville) for their technical assistance. The work was supported by funds from the Milk Check-Off program established by Southeast Milk Inc. (Belleview, FL).

\section{REFERENCES}

Bannerman, D. D., M. J. Paape, W. R. Hare, and E. J. Sohn. 2003. Increased levels of LPS-binding protein in bovine blood and milk following bacterial lipopolysaccharide challenge. J. Dairy Sci. $86: 3128-3137$.

Isobe, N., K. Morimoto, J. Nakamura, A. Yamasaki, and Y. Yoshimura. 2009. Intramammary challenge of lipopolysaccharide stimulates secretion of lingual antimicrobial peptide into milk of dairy cows. J. Dairy Sci. 92:6046-6051.

Kościuczuk, E. M., P. Lisowski, J. Jarczak, J. Krzyzewski, L. Zwierzchowski, and E. Bagnicka. 2014. Expression patterns of betadefensin and cathelicidin genes in parenchyma of bovine mammary gland infected with coagulase-positive or coagulase-negative Staphylococci. BMC Vet. Res. 10:246.

Lippolis, J. D., T. A. Reinhardt, J. P. Goff, and R. L. Horst. 2006. Neutrophil extracellular trap formation by bovine neutrophils is not inhibited by milk. Vet. Immunol. Immunopathol. 113:248-255.

Lippolis, J. D., T. A. Reinhardt, R. A. Sacco, B. J. Nonnecke, and C D. Nelson. 2011. Treatment of an intramammary bacterial infection with 25-hydroxyvitamin $\mathrm{D}_{3}$. PLoS One 6:e25479.

Liu, P. T., S. Stenger, H. Li, L. Wenzel, B. H. Tan, S. R. Krutzik, M. T. Ochoa, J. Schauber, K. Wu, C. Meinken, D. L. Kamen, M. Wagner, R. Bals, A. Steinmeyer, U. Zugel, R. L. Gallo, D. Eisenberg, M. Hewison, B. W. Hollis, J. S. Adams, B. R. Bloom, and R. L. Modlin. 2006. Toll-like receptor triggering of a vitamin D-mediated human antimicrobial response. Science 311:1770-1773.

McDermott, C. M., D. C. Beitz, E. T. Littledike, and R. L. Horst 1985. Effects of dietary vitamin $\mathrm{D}_{3}$ on concentrations of vitamin $\mathrm{D}$ and its metabolites in blood plasma and milk of dairy cows. J. Dairy Sci. 68:1959-1967.

Merriman, K. E., M. F. Kweh, J. L. Powell, J. D. Lippolis, and C. D. Nelson. 2015. Multiple $\beta$-defensin genes are upregulated by the vitamin D pathway in cattle. J. Steroid Biochem. Mol. Biol. 154:120-129.

Merriman, K. E., M. B. Poindexter, M. F. Kweh, J. E. Santos, and C. D. Nelson. 2017. Intramammary 1,25-dihydroxyvitamin $\mathrm{D}_{3}$ treatment increases expression of host-defense genes in mammary immune cells of lactating dairy cattle. J. Steroid Biochem. Mol. Biol. 173:33-41.

Meyer, M. B., P. D. Goetsch, and J. W. Pike. 2010. A downstream intergenic cluster of regulatory enhancers contributes to the induction of CYP24A1 expression by 1 $\alpha, 25$-dihydroxyvitamin $\mathrm{D}_{3}$. J. Biol. Chem. 285:15599-15610.

Nelson, C. D., J. D. Lippolis, T. A. Reinhardt, R. E. Sacco, J. L. Powell, M. E. Drewnoski, M. O'Neil, D. C. Beitz, and W. P. Weiss 
2016a. Vitamin D status of dairy cattle: Outcomes of current practices in the dairy industry. J. Dairy Sci. 99:10150-10160.

Nelson, C. D., B. J. Nonnecke, T. A. Reinhardt, W. R. Waters, D. C. Beitz, and J. D. Lippolis. 2011. Regulation of Mycobacterium-specific mononuclear cell responses by 25 -hydroxyvitamin $\mathrm{D}_{3}$. PLoS One 6:e21674.

Nelson, C. D., J. L. Powell, D. M. Price, M. J. Hersom, J. V. Yelich, M. E. Drewnoski, S. L. Bird, and G. A. Bridges. 2016b. Assessment of serum 25-hydroxyvitamin D concentrations of beef cows and calves across seasons and geographical locations. J. Anim. Sci. 94:3958-3965.

Nelson, C. D., T. A. Reinhardt, D. C. Beitz, and J. D. Lippolis. 2010a. In vivo activation of the intracrine vitamin $\mathrm{D}$ pathway in innate immune cells and mammary tissue during a bacterial infection. PLoS One 5:e15469.

Nelson, C. D., T. A. Reinhardt, T. C. Thacker, D. C. Beitz, and J. D. Lippolis. 2010b. Modulation of the bovine innate immune response by production of $1 \alpha, 25$-dihydroxyvitamin $\mathrm{D}_{3}$ in bovine monocytes. J. Dairy Sci. 93:1041-1049.

Norman, A. W. 2008. From vitamin D to hormone D: Fundamentals of the vitamin D endocrine system essential for good health. Am. J. Clin. Nutr. 88:491S-499S.

NRC. 2001. Nutrient Requirements of Dairy Cattle. 7th rev. ed. Natl. Acad. Press, Washington, DC

Rainard, P., and C. Riollet. 2006. Innate immunity of the bovine mammary gland. Vet. Res. 37:369-400.

Reinhardt, T. A., N. J. Koszewski, J. Omdahl, and R. L. Horst. 1999. 1,25-Dihydroxyvitamin $\mathrm{D}_{3}$ and 9-cis-retinoids are synergistic regu- lators of 24-hydroxylase activity in the rat and 1,25-dihydroxyvitamin $\mathrm{D}_{3}$ alters retinoic acid metabolism in vivo. Arch. Biochem. Biophys. 368:244-248.

Reinhardt, T. A., R. E. Sacco, B. J. Nonnecke, and J. D. Lippolis. 2013. Bovine milk proteome: Quantitative changes in normal milk exosomes, milk fat globule membranes and whey proteomes resulting from Staphylococcus aureus mastitis. J. Proteomics 82:141-154.

Ruegg, P. L. 2012. Mastitis in dairy cows. Vet. Clin. North Am. Food Anim. Pract. 28:xi-xii.

Sadeghi, K., B. Wessner, U. Laggner, M. Ploder, D. Tamandl, J. Friedl, U. Zügel, A. Steinmeyer, A. Pollak, E. Roth, G. Boltz-Nitulescu, and A. Spittler. 2006. Vitamin $\mathrm{D}_{3}$ down-regulates monocyte TLR expression and triggers hyporesponsiveness to pathogen-associated molecular patterns. Eur. J. Immunol. 36:361-370.

Schmitz, S., M. W. Pfaffl, H. H. Meyer, and R. M. Bruckmaier. 2004 Short-term changes of mRNA expression of various inflammatory factors and milk proteins in mammary tissue during LPS-induced mastitis. Domest. Anim. Endocrinol. 26:111-126.

Stoffels, K., L. Overbergh, A. Giulietti, L. Verlinden, R. Bouillon, and C. Mathieu. 2006. Immune regulation of 25-hydroxyvitamin- $\mathrm{D}_{3}-1 \alpha-$ hydroxylase in human monocytes. J. Bone Miner. Res. 21:37-47.

Tetens, J., J. J. Friedrich, A. Hartmann, M. Schwerin, E. Kalm, and G. Thaller. 2010. The spatial expression pattern of antimicrobial peptides across the healthy bovine udder. J. Dairy Sci. 93:775-783.

Vidal, M., C. V. Ramana, and A. S. Dusso. 2002. Stat1-vitamin D receptor interactions antagonize 1,25-dihydroxyvitamin D transcriptional activity and enhance stat1-mediated transcription. Mol. Cell. Biol. 22:2777-2787. 